Approved for public release; distribution is unlimited

\title{
Ecological Survey of M-Field, Edgewood Area Aberdeen Proving Ground, Maryland
}
J. L. Downs
L. E. Eberhardt
R. E. Fitzner
L. E. Rogers

December 1991

Prepared for Chemical Research, Development and Engineering Command U.S. Army Aberdeen Proving Ground, Maryland under a Related Services Agreement with the U.S. Department of Energy under Contract DE-AC06-76RLO 1830

Pacific Northwest Laboratory Operated for the U.S. Department of Energy by Battelle Memorial Institute 


\title{
DISCLAIMER
}

This report was prepared as an account of work sponsored by an agency of the United States Government. Neither the United States Government nor any agency thereof, nor Battelle Memorial Institute, nor any of their employees, makes any warranty, expressed or implied, or assumes any legal liability or responsibility for the accuracy, completeness, or usefulness of any information, apparatus, product, or process disclosed, or represents that its use would not infringe privately owned rights. Reference herein to any specific commercial product, process, or service by trade name, trademark, manufacturer, or otherwise does not necessarily constitute or imply its endorsement, recommendation, or favoring by the United States Government or any agency thereof, or Battelle Memorial Institute. The views and opinions of authors expressed herein do not necessarily state or reflect those of the United States Government or any agency thereof.

\author{
PACIFIC NORTHWEST LABORATORY \\ operated by \\ BATTELLE MEMORIAL INSTITUTE \\ for the \\ UNITED STATES DEPARTMENT OF ENERGY \\ under Contract DE-AC06-76RLO 1830
}

Printed in the United States of America

Available to DOE and DOE contractors from the

Office of Scientific and Technical Information, P.O. Box 62, Oak Ridge, TN 37831; prices available from (615) 576-8401. FTS 626-8401.

Available to the public from the National Technical Information Service, U.S. Department of Commerce, 5285 Port Royal Rd., Springfield, VA 22161. 

J. L. Downs
L. E. Eberhardt
R. E. Fitzner
L. E. Rogers

December 1991

Prepared for

Chemical Research, Development and Engineering Command U.S. Army Aberdeen Proving Ground, Maryland under a Related Services Agreement with the U.S. Department of Energy Contract DE-AC06-76RLO 1830 


\section{SUMMARY}

An ecological survey was conducted on M-Field, at the Edgewood Area, Aberdeen Proving Ground, Maryland. This study was conducted for the U.S. Department of the Army, Chemical Research and Development Engineering Center, by Pacific Northwest Laboratory. M-Field is used routinely to test army smokes and obscurants, including brass flakes, carbon fibers, and fog oils. The field has been used for testing purposes for the past 40 years, but little documented history is available. Under current environmental regulations, the test field must be assessed periodically to document the presence or potential use of the area by threatened and endangered species.

The M-Field area is approximately 370 acres and is part of the U.S. Army's Edgewood Area at Aberdeen Proving Ground in Harford County, Maryland. The grasscovered field is primarily lowlands with elevations from about 1.0 to $8 \mathrm{~m}$ above sea level, and several buildings and structures are present on the field. The ecological assessment of M-Field was conducted in three stages, beginning with a preliminary site visit in May to assess sampling requirements. Two field site visits were made June 3-7, and August 12-15, 1991, to identify the biota existing on the site. Data were gathered on vegetation, small mammals, invertebrates, birds, large mammals, amphibians, and reptiles.

In addition to the release of smokes and obscurants on M-Field, the area is subject to disturbance from mowing and heavy equipment traffic. Portions of $M$-Field are routinely mowed to decrease the potential for fire during obscurant testing. Comparisons of data on areas of M-Field with known exposure to smokes with data from areas believed to have no or relatively little exposure to smokes showed no significant differences between areas. Comparison of data from areas that are routinely mowed with data from areas that were not subject to mowing at the time of the surveys showed differences in mean percent cover of sedges in June and mean percent cover of grasses for the August sampling. Data from the small mammal trapping indicated differences in the use of mowed versus unmowed areas by small mammals. There were no significant 
differences in mean percent cover of sedges in June and mean percent cover of grasses for the August sampling. Data from the small mammal trapping indicated differences in the use of mowed versus unmowed areas by small mammals. There were no significant differences in the average abundance of invertebrates inhabiting the mowed and unmowed areas.

The two surveys of the area documented a number of plant and animal species found on and near M-Field. The only endangered species noted on M-Field was the bald eagle (Haliaeetus leucocephalus), which was feeding on the field. 


\section{ACKNOWLEDGMENTS}

We would like to extend thanks to Dr. Randy Wentsel and Dr. Carl Phillips of the U.S. Army's Chemical Research, Development and Engineering Command at Edgewood Area. Their assistance and advice were greatly appreciated. In addition, we would like to thank Dr. John Thomas of Pacific Northwest Laboratory for his help and review of this project. The assistance of Todd Chadwell, working as an undergraduate student in the Science and Engineering Semester Program under the Northwest Organization of Colleges and Universities for the Advancement of Science, is also greatly appreciated. 


\section{CONTENTS}

SUMMARY $\ldots \ldots \ldots \ldots \ldots \ldots \ldots \ldots \ldots \ldots \ldots \ldots \ldots \ldots \ldots \ldots$ iii

ACKNOWLEDGMENTS $\ldots \ldots \ldots \ldots \ldots \ldots \ldots \ldots \ldots \ldots \ldots$

INTRODUCTION $\ldots \ldots \ldots \ldots \ldots \ldots \ldots \ldots \ldots \ldots \ldots \ldots \ldots \ldots \ldots \ldots \ldots \ldots$

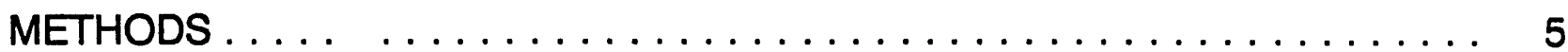

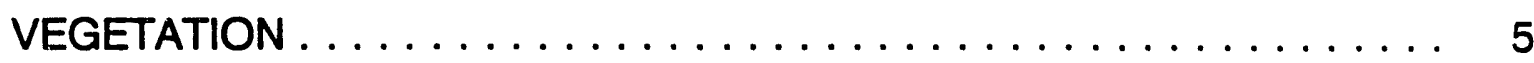

SMALL MAMMAL TRAPPING $\ldots \ldots \ldots \ldots \ldots \ldots \ldots \ldots \ldots$

BIRD SURVEYS $\ldots \ldots \ldots \ldots \ldots \ldots \ldots \ldots \ldots \ldots \ldots \ldots \ldots \ldots$

INVERTEBRATE SURVEYS $\ldots \ldots \ldots \ldots \ldots \ldots \ldots \ldots \ldots \ldots$

RESULTS AND DISCUSSION $\ldots \ldots \ldots \ldots \ldots \ldots \ldots \ldots \ldots \ldots$

VEGETATION SAMPLING $\ldots \ldots \ldots \ldots \ldots \ldots \ldots \ldots \ldots \ldots \ldots$

SMALL MAMMAL TRAPPING $\ldots \ldots \ldots \ldots \ldots \ldots \ldots \ldots \ldots \ldots, 12$

OTHER MAMMALS $\ldots \ldots \ldots \ldots \ldots \ldots \ldots \ldots \ldots \ldots \ldots \ldots$

BIRD SURVEYS $\ldots \ldots \ldots \ldots \ldots \ldots \ldots \ldots \ldots \ldots \ldots \ldots \ldots \ldots$

REPTILES AND AMPHIBIANS $\ldots \ldots \ldots \ldots \ldots \ldots \ldots \ldots \ldots \ldots$

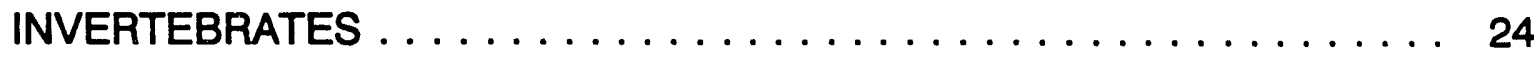

Sweep Net Samples . . . . . . . . . . . . . . . . 23

Litter Samples ........................ 24

CONCLUSIONS $\ldots \ldots \ldots \ldots \ldots \ldots \ldots \ldots \ldots \ldots \ldots \ldots \ldots \ldots \ldots \ldots \ldots$

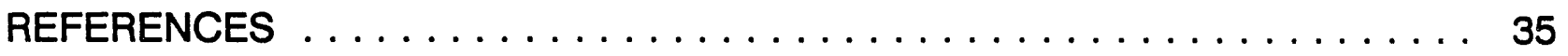

APPENDIX A - COORDINATES OF SAMPLING TRANSECTS ON M-FIELD . . . A.1 
APPENDIX B - MEASUREMENTS OF PERCENT COVER . . . . . . . B.1

VEGETATION ON M-FIELD TRANSECTS

APPENDIX C - LIST OF RARE, THREATENED, AND ENDANGERED

VERTEBRATES THAT COULD OCCUR AT M-FIELD . . . . . . C. 1

APPENDIX D - TERRESTRIAL VERTEBRATES OF MARYLAND FOUND

AT ABERDEEN THAT COULD OCCUR AT M-FIELD . . . . . . . D.1 


\section{FIGURES}

1 M-Field Area and Location of Transects $\ldots \ldots \ldots \ldots \ldots \ldots \ldots$

2 Mean Percent Canopy Cover of Grasses of M-Field in June and

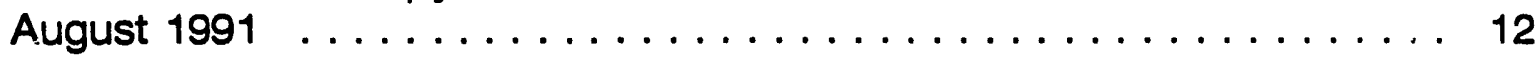

3 Mean Percent Canopy Cover of Sedges of M-Field in June and

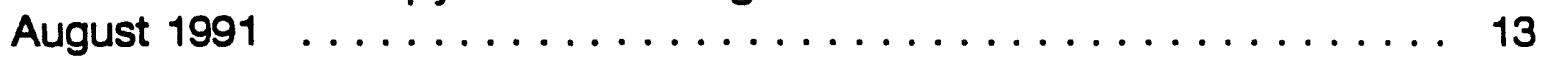

4 Mean Percent Canopy Cover of Forbs on M-Field in June and August $1991 \ldots \ldots \ldots \ldots \ldots \ldots \ldots \ldots \ldots \ldots \ldots \ldots$

\section{TABLES}

1 Plant Species Found on M-Field $\ldots \ldots \ldots \ldots \ldots \ldots \ldots \ldots$

2 Summary of Small Mammals Live Trapped on M-Field in June and

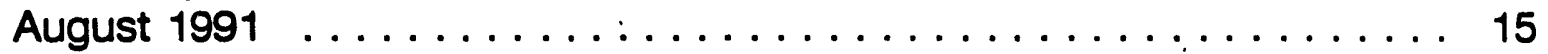

3 Summary of Mammals Observed on M-Field in June and August 1991 . 16

4 Birds Observed on an Adjacent to M-Field in June and August $1991 \ldots 18$

5 Number and Species of Birds Observed on M-Field on June 4,

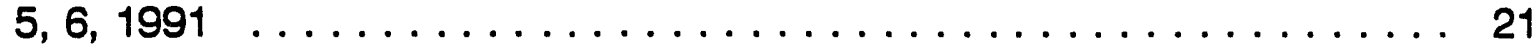

6 Number and Species of Birds Observed on M-Field orl August 14

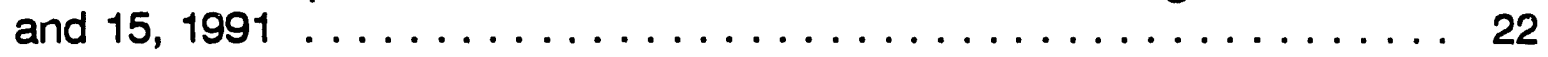

7 Between Plot Comparisons for Invertebrates Collected at M-Field . . . . 24

8 Invertebrates Collected at M-Field: Sweep Net Samples . . . . . . . . 25

9 Invertebrates Collected at M-Field: Litter Samples $\ldots \ldots \ldots \ldots \ldots$ 


\section{INTRODUCTION}

The 370-acre area designated as M-Field has been used to test smokes and obscurants for the past 40 years. Since World War II, tests of other munitions or chemicals at the field are believed to have been minimal. (The history of M-field before World War II is not documented.) These tests have resulted in the exposure of flora and fauna inhabiting M-Field to smokes and perhaps other chemicals. An ecological survey was required to meet environmental regulations and to assess whether any chronic effects to biota from these exposures or any significant ecological impacts of the testing could be detected.

The vegetation of the $M$-Field area is dominated by grasses and sedges, and forbs are an important component of understory and ground cover. A few scattered shrubs and vines exist on the field as well, but no large woody shrubs or trees are located on the field. Deciduous trees and shrubs do occur at the perimeters of M-Field (Figure 1). Several structures are located on the field, including a large cement pad, a scaffolding-like framework, construction trailer, and a bermed bunker-type structure.

The field is low lying with elevations of 1.0 to $8.0 \mathrm{~m}$ above sea level. Soils at $M-F i e l d$ are in the Sassatras and Elkton series. The Sassafras soils occur on the higher elevations of the field and consist of deep, well-drained soils that originated from old marine deposits containing sand with minor amounts of silts and clays. The Elkton soils occur at the lower elevations and consist of deep, poorly drained soils formed in old deposits of clay marine sediments. Areas of M-Field below 2-m elevation were visibly mesic or wet throughout the summer. The mean annual precipitation of the area is $116 \mathrm{~cm}$ (45.8 in.).

M-Field is subject to two types of disturbance in association with obscurant testing. The first disturbance is the introduction of contaminants to the ecosystem from the smokes or obscurants. The second level of disturbance is that resulting from 

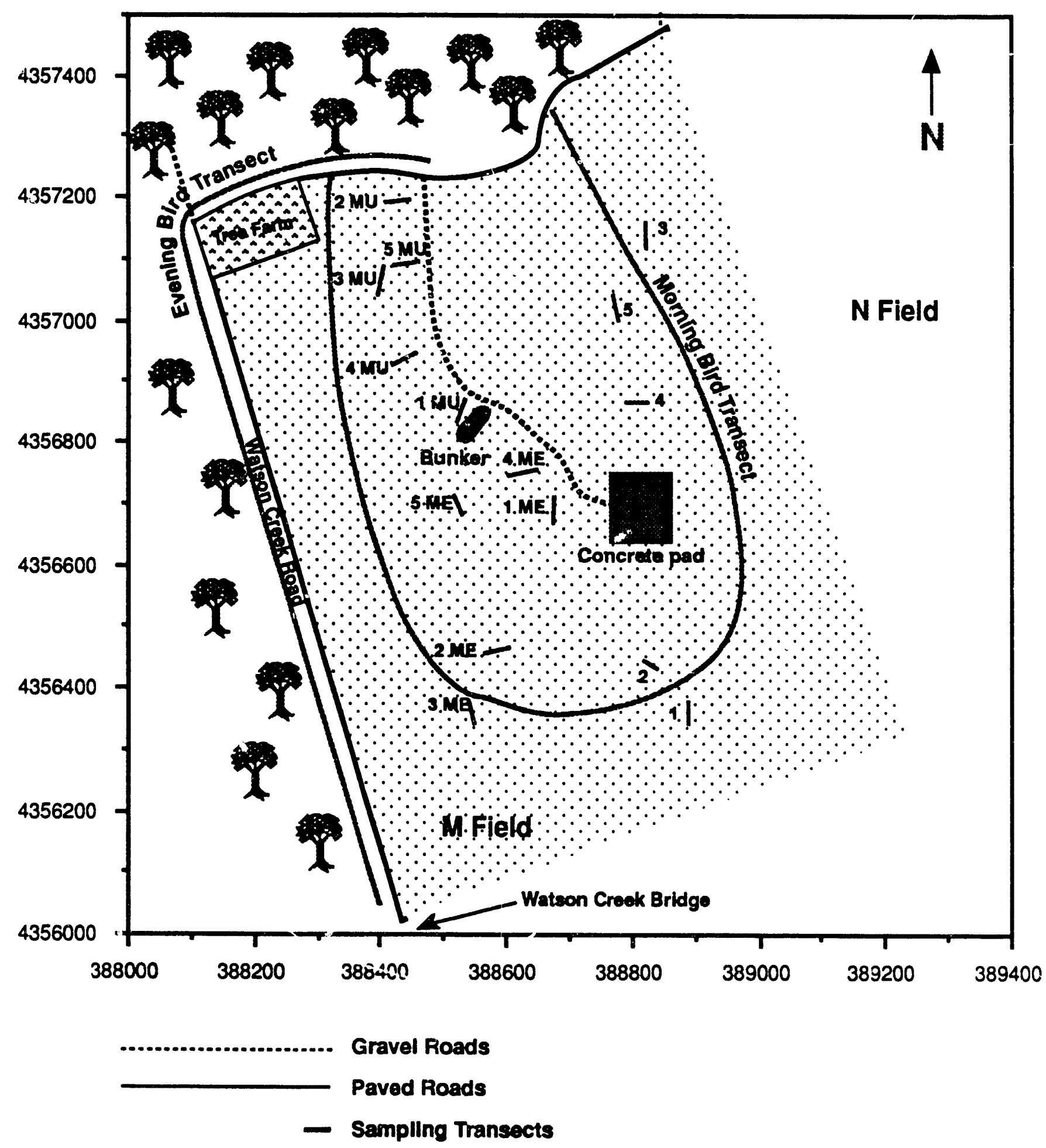

FIGURE 1. M-Field Area and Location of Transects. $X$ and $Y$ axes are Universal Transverse Mercator System Grid coordinates. 
physical activities, that is, driving of heavy equipment across the field and routine mowing of portions of the field to alleviate fire hazard.

The primary objective of this survey was to document the flora and fauna inhabiting the field. Sampling of the area was also designed to test for differences in vegetation composition and canopy cover, invertebrate composition, and the relative abundance of small mammals in areas with different disturbance histories. 


\section{METHODS}

Primary sampling transects were randomly assigned to areas of $M$-Field according to three designations: 1) unmowed, unexposed transects (nos. 1-5 in Figure 1), 2) mowed, unexposed transects (nos. 1MU-5MU in Figure 1), and 3) mowed, exposed transects (nos. 1ME-5ME in Figure 1). The designated areas were identified after discussions with Chemical Research and Development Engineering Center (CRDEC) staff during the prelimiriary visit to the field site. The southwestern quadrant of the field (that area south and west of the bunker) was determined to be used for testing and routinely mowed. The northwestern portion of M-Field was described as being routinely mowed but receiving relatively little or no exposure to smokes. The eastern half of $M$-Field had little to no exposure to smokes and was not mowed. Both the location and orientation of the transects are shown in Figure 1. Plastic stakes were used to mark the location of each 50-m transect, and a Geographic Positioning System (GPS) was used to determine the position of each transect and map prominent features of M-Field in Universal Tranverse Mercator System Grid Coordinates (UTM) using satellite information. Appendix A lists the UTM coordinates of each of the sampling transects. These transects were used as the sampling units and thus the areas where information was gathered on vegetation, small mammals, and invertebrates on $\mathrm{M}$-Field.

\section{VEGETATION}

Each 50-m transect was sampled to determine species composition and estimate canopy cover along the transect. Plant canopy cover was estimated using a modified Daubenmire plot (Daubenmire 1959). The Dauberımire plot is a rectangular plot frame, $20 \mathrm{~cm}$ by $50 \mathrm{~cm}\left(0.1 \mathrm{~m}^{2}\right)$. The plot frame was modified by using taut string to evenly divide the frame into 10 equal boxes and aid in estimating percent cover. The canopy cover was visually estimated by holding the frame over the vegetation and looking directly down. The percentage of the plot frame, from 1 to $100 \%$, was recorded for each species occurring within the bounds of the plot frame. All visual estimates of canopy cover were 
performed by the same person to ensure consistency in the data.

Ten samples were taken on each transect at 5-m intervals. Species were identified when possible or gathered for later identification. Identifying grass species on closely mown transects was extremely difficult and often could not be accomplished with any certainty. During each field site visit, some transects had been recently mowed, and some were mowed during the sampling effort. In addition to listing species identified on transects, efforts were made to identify and list all other plant species encountered on M-Fieíd, including species seen and collected during the preliminary site visit in the spring.

Data were analyzed by grouping species canopy cover into three categories: grasses, forbs, and sedges. The data were transformed for analysis using arcsin $\sqrt{y}$, which is recommended by Steel and Torrie (1980) for percentages covering a wide range of values. Statistical comparisons of plant canopy cover by area (unmowed, unexposed; mowed, unexposed; mowed, exposed) were done using one-way analysis of variance techniques. If analysis of variance indicated a difference in mean values, Duncan's Multiple Range Test was applied. Significant differences were determined at the $5 \%$ level $(p=0.05)$.

\section{SMALL MAMMAL TRAPPING}

Live trapping for small mammalswas done along all 15 primary sampling transects (Figure 1). Two 100-m long transects were placed parallel to and $10 \mathrm{~m}$ away on each side of the primary sampling transects. Sherman live iraps were placed at $10-\mathrm{m}$ intervals along each of the two small mammal transects for a total of 20 traps per primary sampling transect. Traps were baited with a mixture of rolled oats and peanut butter and were checked in the mornings. Species and sex of each captured 
small mammal were determined, and each mammal was classified into adult or juvenile age categories. All mice were weighed to the nearest $0.5 \mathrm{~g}$.

\section{BIRD SURVEYS}

A transect line was established through M-Field (Figure 1), and this path was walked by an observer on June 4, 5, and 6 and August 14 and 15, 1991. All birds observed within $100 \mathrm{~m}$ of either side of the transect were counted. The June 4 survey was conducted in the evening from 1830 to 1930 hours. The June 5 and 6 surveys were morning surveys, beginning at 0610 and ending at 0800 hours. The August 14 and 15 surveys of M-Field birds began at 0600 hours and ended at 0730 hours. Two evening bird transects, one in June and one in August, were also walked around the Watson Creek Road (Figure 1). These surveys included birds observed on M-field and birds associated with wooded, bay, and marsh habitats.

\section{INVERTEBRATE SUIRVEYS}

Invertebrate populations were sampled by using sweep nets and by collecting soil/itter samples. Insects were collected on each of the 15 sampling transects using a 12-in.-diameter insect sweep net. The net was swept side to side through vegetation in an arc approximately $1-m$ wide. Fifty consecutive sweeps were made in each transect. The net and contents were stuffed into an insect killing jar containing a cotton swab saturated with ethyl acetate as a killing agent. After the insects were immobilized, they were emptied into a pint jar containing $72 \%$ ethanol. They were stored in this solution for later identification.

A soil litter sample was collected at each transect: a core 4 in. in diameter by 6 in. deep was dug with a metal trowel. Each sample was placed in a plastic bag labeled, and stored. These samples were flown to our laboratory where each was placed in a berelese funnel. The amount of time lapsed between collection and 
placement in the funnel was approximately 24 hours. Invertebrates were captured in glass jars filled with $72 \%$ ethanol at the bottoms of the berelese funnels and stored for identification.

Invertebrate identifications were made with the aid of a variable (0-70 power magnification) microscope. The nomenclature follows that of Borror et al. (1976) for adult specimens and Chu (1949) for immature life stages.

A Shannon information index (Shannon and Weaver 1949) was used as a measure of invertebrate diversity.

$$
H^{\prime}=\sum_{i=1}^{S} P_{i} \log _{e} P_{i}
$$

where $H^{\prime}$ equals the diversity index, and $P_{i}$ equals the proportion of the total number of individuals that belong to the ith taxa. An evenness index (J') (Pielou 1969) was also calculated:

$$
J ' \frac{H^{\prime} \text { observed }}{H^{\prime} \text { maxinivimm }}
$$

$J$ ' is a measure of the distribution of the invertebrates among tine various taxa present. A value of 1.0 would indicate an equal number of specimens in each taxa. Richness (S) or the nurnber of taxa present is also documented. The Bonferroni t-test was used to test for significant differences between mean values (Miller 1966). All tests were conducted at the $\alpha 0.05$ level. 


\section{RESULTS AND DISCUSSION}

\section{VEGETATION SAMPLING}

The plant species identified at M-Field during the May, June, and July visits are listed in Table 1. Mowing of the field during sampling in June and August complicated plant identification on those transects that were mowed. The mean percent co:er for grasses, sedges, and forbs was calculated from the transect sampling data and is shown in Figures 2-4. Mean percent cover of sedges and forbs decreased from June to August, while the mean percent cover of grasses increased in all areas as the summer progressed.

A one-way analysis of variance of the data gathered in June showed no significant difference in the mean percent cover of grasses or forbs between any of the groupings of transects (e.g., mowed, unmowed, exposed, unexposed). Analysis of variance did indicate differences in mean percent cover of sedges on the mowed, unexposed (MU) transects compared with the unmowed unexposed transects (UU) $(F=4.29, d f=2,12, p=0.03$ ). Comparisons of vegetation data from the August sampling showed significant differences $(F=9.83, d f=2,12, p=0.003$ ) between mean percent cover of grasses on the MU-transects and grasses on the UU-transects and MEtransects. The significantly lower grass cover on the MU-transects seemed to reflect greater disturbance of those areas by driving and parking large equipment across portions of the area. The ground surface on transects near the gravel roadway appeared to be hard packed. Two of these transects (Transects $2 \mathrm{MU}$ and $5 \mathrm{MU}$ ) also appeared to have a white crust on much of the bare ground. The appearance of the white powdery crust may indicate that this area had been used in the past as a testing ground and did not adequately represent an unexposed condition. The difference in percent cover of sedges in the June sampling may be related to the topography of $\mathrm{M}$ Field. In general, sedges at M-Field are more likely to be found at wetter, lower elevations. Three of the randomly assigned transects for this area were near the 
TABLE 1. Plant Species Found on M-Field

Grasses

Agrostis stolonifera Andropogon virginicus Anthoxanthum odoratu Aristida oligantha Cynodon dactylon Eragrostis spectabilis Festuca rubra Holcus lanatus Panicum spp.

Paspalum pubescens

Poa praetensis

Phragmites sp.

Setaria geniculata

Sorghastrum nutans

Tripsacum dactyloides

Unknown grasses

Sedges and Rushes

Carex annectans

Carex granularis

Carex squarrosa

Carex tribuloides

Eleocharis tenuis

Juncus effuses

Juncus tenuis

Scirpus atrovirens
Common Names

Red top

Broom sedges

Sweet vernal grass

Three-awn

Bermuda grass

Purple love grass

Red fescue

Velvet grass

Panic grass

Reed

Fox-tail

Indian grass

Gama grass

Meadow sedge

Spike rush

Soft rush

Path rush

Dark green bulrush 
TABLE 1. (contd)

Forbs

Allium vineale
Cassia fasciculata
Chrysanthemum leucanthemum
Cichorium intybus
Claytonia virginica
Duchesnea indica
Erigeron strigosus
Liquidamber styraciflua
Galium sp.
Osmunda regalis
Penstemon digitalis
Plantago lanceolata
Potentilla sp.
Oxalis sp.
Ranunculus sp.
Rudbeckia hirta
Rumex acetosella
Scutellaris integrifolia
Sisyrinchium arenicola
Solenum carolinense
Trifolium sp.
Typhia latifolia
Viola sp.
Unknown forbs

Field garlic

Wild senna

Ox-eye daisy

Chicory

Spring beauty

Indian strawberry

Daisy

Sweetgum

Bedstraw

Royal fern

Foxglove beardtongue

Plantain

Cinquefoil

Wood-sorrel

Buttercup

Black-eyed susan

Sheep sorrel

Hyssop skullcap

Blue-eyed grass

Horse nettle

Cattail

Clover

Violet 


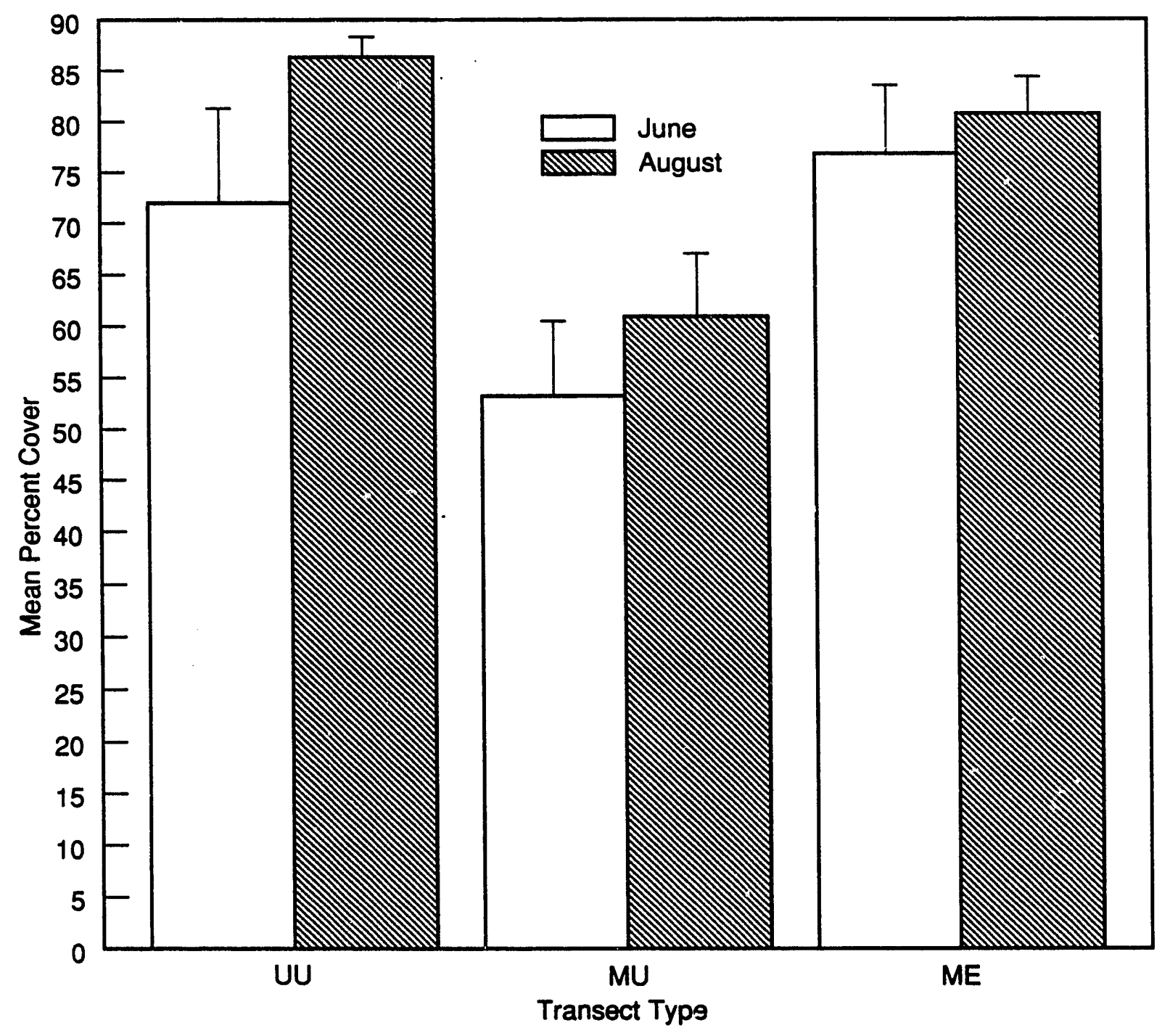

FIGURE 2. Mean Percent Canopy Cover of Grasses on M-Field in June and August 1991 (error bars are one standard error)

roadway and at higher elevation than most of the other transects. These transects visibly appeared to be under more water stress than transects at lower elevations. 
SMALL MAMMAL TRAPPING

Small mammal trapping was conducted from June 4-6 and August 15-16, 1991, for a total of 1,300 trap-nights. Three species of small mammals were captured

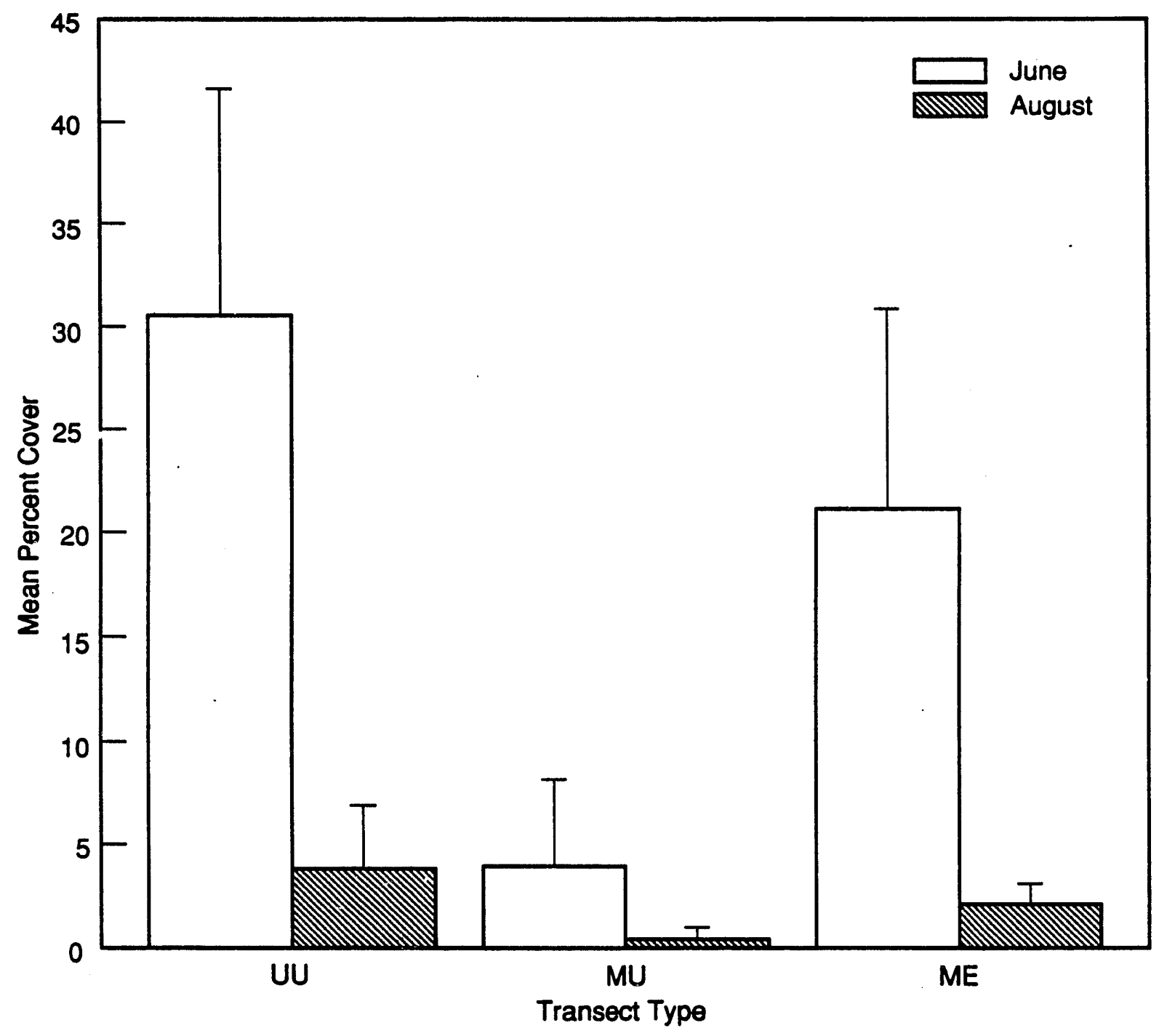

FIGURE 3. Mean Percent Canopy Cover of Sedges on M-Field in June and August 1991 (error bars are one siandard error) 
(Table 2). The meadow vole (Microtus pennsylvanicus) was by far the most common small mammal captured, with a trapping success of 0.02 captured per trap-night. The only other species captured were deer mice (Peromyscus maniculatus) and rice rats ( Jryzomys palustris). The only sampling transects on which mice were captured were the four located in the southern part of M-Field (nos. 2ME, 3ME, 2, and 1) and the

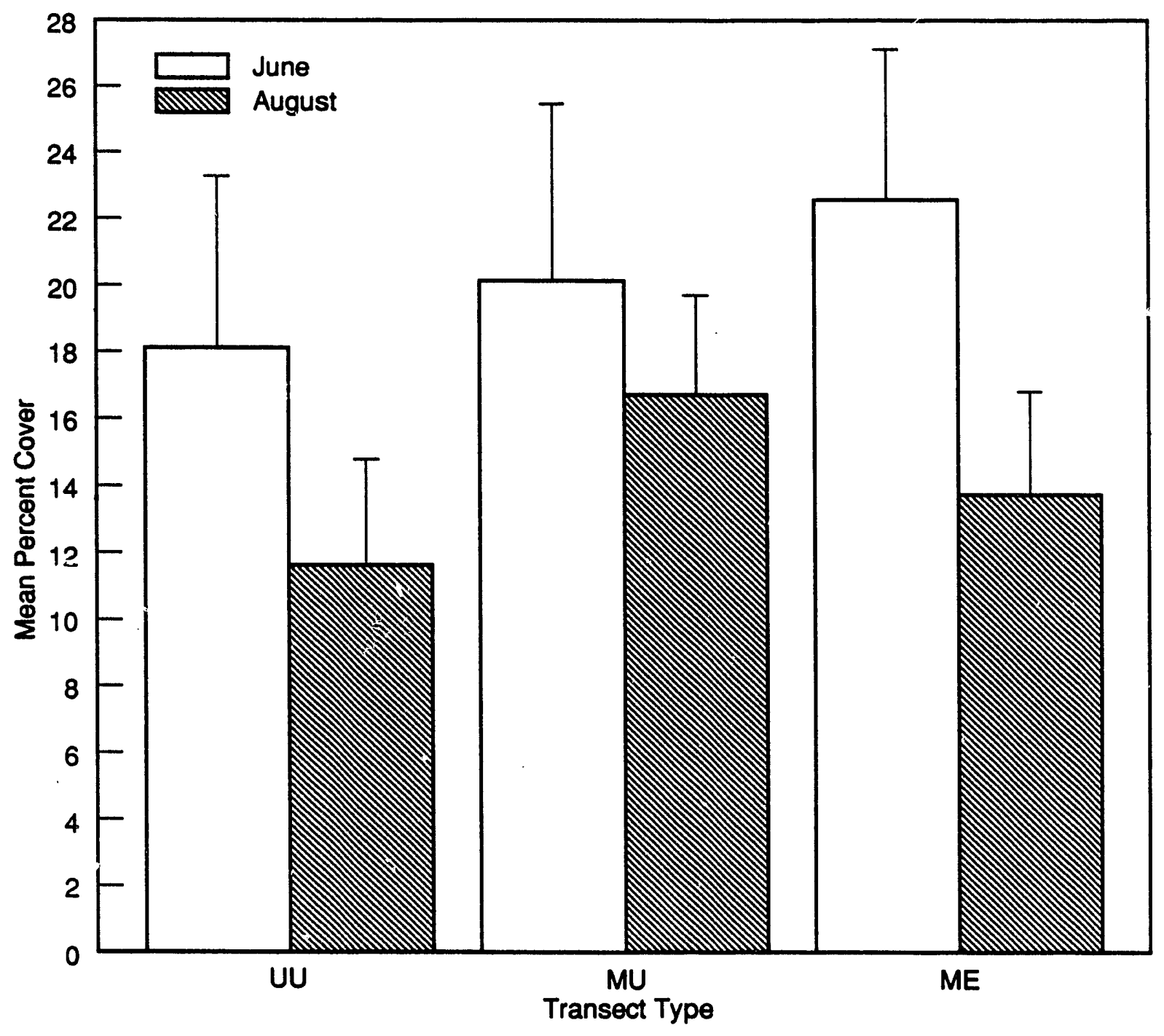

FIGURE 4. Mean Percent Canopy Cover of Forbs on M-Field in June and August 1991 (error bars are one standard error) 
three located on the eastern half (nos. 3, 4, and 5) (Figure 1). Trapping success was highest on sampling transect 2ME (Figure 1). Mowing on these transects was infrequent during the study period, and the grass was tall $(0.5 \mathrm{~m})$ and dense. No

TABLE 2. Summary of Small Mammals Live Trapped on M-Field in June and August 1991

\begin{tabular}{|c|c|c|c|c|c|}
\hline Date & Plot No. & Species & $\operatorname{Age}^{(a)}$ & Sex & Weight (g) \\
\hline $6 / 4 / 91$ & 2ME & Microtus pennsylvanicus & J & $F$ & 15.0 \\
\hline $6 / 5 / 91$ & 2ME & Microtus pennsylvanicus & $J$ & $F$ & 15.5 \\
\hline $6 / 5 / 91$ & 2ME & Microtus pennsylvanicus & $J$ & $\mathbf{F}$ & $15.0^{(a)}$ \\
\hline $6 / 5 / 91$ & 2 & Microtus pennsylvanicus & A & $\mathbf{F}$ & 25.5 \\
\hline $6 / 5 / 91$ & 1 & Microtus pennsylvanicus & A & $\mathbf{F}$ & 43.0 \\
\hline $6 / 5 / 91$ & 3 & Oryzomys palustris & A & $\mathbf{F}$ & 60.0 \\
\hline $6 / 6 / 91$ & 1 & Microtus pennsylvanicus & J & $F$ & 25.0 \\
\hline 6/6/91 & 1 & Microtus pennsylvanicus & A & $F$ & 35.0 \\
\hline $6 / 6 / 91$ & 5 & Oryzomys palustris & A & $F$ & $60.0^{(b)}$ \\
\hline 6/6/91 & 4 & Microtus pennsylvanicus & A & M & 36.0 \\
\hline $6 / 6 / 91$ & 2ME & Microtus pennsylvanicus & $J$ & $M$ & 18.0 \\
\hline $6 / 6 / 91$ & 2ME & Microtus pennsylvanicus & J & $\mathbf{F}$ & 15.5 \\
\hline $8 / 14 / 91$ & 2ME & Peromyscus maniculatus & $J$ & $F$ & 12.0 \\
\hline $8 / 14 / 91$ & 2ME & Microtus pennsylvanicus & A & $F$ & 41.0 \\
\hline $8 / 14 / 91$ & 3ME & Microtus pennsylvanicus & A & M & 33.0 \\
\hline $8 / 14 / 91$ & 2 & Microtus pennsylvanicus & A & $M$ & 57.0 \\
\hline $8 / 14 / 91$ & 1 & Microtus pennsylvanicus & A & $F$ & 38.0 \\
\hline $8 / 14 / 91$ & 1 & Microtus pennsylvanicus & A & $F$ & 550 \\
\hline $8 / 14 / 91$ & 1 & Microtus pennsylvanicus & A & $M$ & 67.0 \\
\hline $8 / 15 / 91$ & 2ME & Peromyscus maniculatus & $J$ & $\mathbf{F}$ & $12.0^{(b)}$ \\
\hline $8 / 15 / 91$ & 3ME & Microtus pennsylvanicus & $J$ & M & 30.0 \\
\hline $8 / 15 / 91$ & 1 & Microtus pennsylvanicus & A & $M$ & 68.0 \\
\hline $8 / 15 / 91$ & 1 & Microtus pennsylvanicus & A & $F$ & 40.0 \\
\hline $8 / 15 / 91$ & 1 & Microtus pennsylvanicus & A & $\mathbf{F}$ & $51.0^{(\mathrm{c})}$ \\
\hline $8 / 15 / 91$ & 1 & Microtus pennsylvanicus & A & $\mathbf{F}$ & $45.0^{(d)}$ \\
\hline $8 / 15 / 91$ & 3 & Microtus pennsylvanicus & A & $F$ & 40.0 \\
\hline
\end{tabular}
(a) $\mathrm{J}=$ juvenile, $\mathrm{A}=$ adult.
(b) Recapture.
(c) Lactating.
(d) Pregnant. 
small mammals were captured on the remaining eight sampling transects. The grass on these transects was mowed very short (10 to $15 \mathrm{~cm}$ tall) and did not provide adequate cover for small marnmals.

\section{OTHEER MAMMALS}

White-tailed deer (Odocoileus virginanus) were very common on M-Field and cculd be observed every morning and evening feeding on the grasses and forbs (Table 3). Occasionally, deer were found bedded in the tall grass in the southern part of M-Field during midday. Most deer activity took place in the southern part of M-

TABLE 3. Summary of Mammals Observed on M-Field in June and August 1991

$\underline{\text { Date }}$

$6 / 3 / 91$

White-tailed deer (Odocoileus virginianus)

Red fox (Vulpes fulva)

Raccoon (Procyon lotor)

Woodchuck (Marmota monax)

6/4/91 White-tailed deer (Odocoileus virginianus) Red fox ('vulpes fulva)

6/5/91 White-tailed deer (Odocoileus virginianus) Woodchuck (Marmota monax) Star-nosed mole (Condylura cristata)

8/13/91 White-tailed deer (Odocoileus virginianus) Red fox (Vulpes fulva) Woodchuck (Marmota monax)

8/14/91 White-tailed deer (Odocoileus virginianus) Red fox (Vulpes fulva)

8/15/91 White-tailed deer (Odocoileus virginianus) Opossum (Didelphis marsupialis)

No. Observed

5

1

1

1

1

5

18

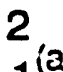

$1^{(a)}$

5

2

2

3

2

5 $1^{(a)}$

(a) Found dead on road near M-Field. 
Field. One fawn, approximately 1 week old, was observed in the norcheast corner of M-Field in June. Woodchucks (Marmota monax) were also common residents on MField. They were observed exclusively in the closely mowed areas around the bunker (Figure 1). A family of red foxes (Vulpes fulva) was also present on M-Field. An adult and four pups were observed in June near the concrete pad (Figure 1) and may have been denning there. Adult and juvenile red foxes were also observed foraging in $M$ Field in August. A single raccoon (Procyon lotor) was observed in June in the northern part of M-Field. In addition, one opossum (Didelphis marsupialis) was observed dead on a road near $M$-Field.

\section{BIRD SURVEYS}

Fifty-one species of birds were observed on and adjacent to M-Field during the morning and evening surveys in June and August (Table 4). Nineteen of these species were observed exclusively in the wooded areas adjacent to M-Field (Table 4). The mute swan (Cygnus olor) and mallard (Anas platyrhynchos) were observed on the Watson Creek Wildlife Refuge at Watson Creek Bridge at the southern end of M-Field.

During the June M-Field bird surveys, 26 species were observed. The eastern meadowlark (Sturnella magna) and grasshopper sparrow (Ammodrammus sarannarum) were the most abundant birds observed. Territorial males were found singing, and the breeding season was at its height. The eastern bluebird (Sialia sialis), red-winged blackbird (Angelaius phoeniceus), and several other passerine species were singing and breeding in the area. Tree and barn swallows (Tachycineta bicolor, Hirundo rustica) were present, but not numerous over the fields. Males of the northern bobwhite (Colinus virginianus) and ring-necked pheasant (Phaesianus colchicus) (gamebirds) were heard singing, indicating that the species probably nested on M-Field. Four birds of prey were observed (Table 5). The bald eagle (Haliaeetus leuco cephalus), listed as an endangered species by the U.S. Fish and Wildlife Service, was observed on the ground at M-Field feeding on the carcass of a 
TABLE 4. Birds Observed on and Adjacent to M-Field in June and August 1991

Family - Ardeidae

Green-backed heron (Butorides striatus)

Great egret (Casmerodius albus)

Great blue heron (Ardea herodias)

Family - Anatidae

Mute swan (Cygnus olor) *

Canada goose (Branta canadensis)

Mallard (Anas platyrhynchos)*

Family - Charadriidae

Killdeer (Charadrius vociferus)

Family - Laridae

Herring gull (Larus argentatus) *

Family - Cathartidae

Turkey vulture (Cathartes aura)

Family - Accipitridae

Bald eagle (Haliaeetus leucocephalus)

Red-tailed hawk (Buteo jamaicensis)

Osprey (Pandion haliaetus)

Family - Falconidae

American kestrel (Falco sparverius)

Family - Phasianidae

Northern bobwhite (Colinus virginianus)

Ring-necked pheasant (Phasianus colchicus)

Family - Columbidae

Mourning dove (Zenaida macroura)

Family - Cuculidae

Yellow-billed cuckoo (Coccyzus americanus) * 
TABLE 4. (contd)

Family - Picidae

Northern flicker (Colaptes auratus)

Hairy woodpecker (Picoides villosus) *

Family - Tyrannidae

Eastern kingbird (Colaptes auratus )

Eastern wood-pewee (Contopus virens) *

Family - Hirundinidae

Tree swallow (Tachycineta bicolor)

Purple martin (Progne subis)

Barn swallow (Hirundo rustica)

Family - Corvidae

Blue jay (Cyanocitta cristata)

American crow (Corvus brachyrhynchos)

Family - Paridae

Black-capped chickadee (Parus atricapillus) *

Family - Troglodytidae

Carolina wren (Thryothorus ludovicianus) *

Family - Muscicapidae

Eastern bluebird (Sialia sialis)

American robin (Turdus migratorius) *

Hermit thrush (Catharus guttatus) *

Family - Mimidae

Northern mockingbird (Mimus polyglottos)

Brown thrasher (Toxostoma rufum) *

Gray catbird (Dumatella carolinensis) * 
TABLE 4. (contd)

Family - Sturnidae

European starling (Sturnus vulgaris)

Family - Vireonidae

Red-eyed vireo (Vireo olivaceus) *

Family - Emberizidae

Yellow warbler (Dendroica petechia) *

Common yellowthroat (Geothlypis trichas)

Northern cardinal (Cardinalis cardinalis) *

Blue grosbeak (Cyanocompsa parellina)

Indigo bunting (Passerina cyanea) *

Rufous-sided towhee (Pipilo erythrophthalamus) *

Grasshopper sparrow (Ammodramus savannarum)

Song sparrow (Melospiza melodia) *

Bobolink (Dolichonjx oryzivorus)

Eastern meadowlark (Sturnella magna)

Red-winged blackbird (Agelaius phoenicei's)

Brown-headed cowbird (Molothrus ater)

Common grackle (Quiscalus quiscula)

Northern oriole (Icterus galbula) *

Family - Fringillidae

American goldfinch (Carduelis tristis)

* = birds observed off M-Field. Restricted to forest, forest edge, or marsh.

dead red fox. One adult eagle and four subadults were sighted feeding on the carcass. Two additional subadults were found perched on a concrete pad in the middle of M-Field.

During the August bird transects, only 22 species were recorded on M-Field (Table 6). Fewer eastern meadowlarks and grasshopper sparrows were observed, indicating that the breeding season had ended and most birds had dispersed 
TABLE 5. Number and Species of Birds Observed on M-Field on June 4, 5, 6, 1991

\begin{tabular}{|c|c|c|}
\hline Species & No. Observed & Activity \\
\hline Great blue heron & 2 & Flying \\
\hline Killdeer & 1 & On ground \\
\hline Turkey vulture & 7 & Flying \\
\hline Bald eagle & $\begin{array}{l}5 \\
2\end{array}$ & $\begin{array}{l}\text { Feeding, standing } \\
\text { Perched }\end{array}$ \\
\hline Red-tailed hawk & 2 & Flying \\
\hline Osprey & 1 & Flying \\
\hline Northern bobwhite & 3 & Perched, singing \\
\hline Ring-necked pheasant & 1 & Standing, ground \\
\hline Mourning dove & 2 & On ground \\
\hline Northern flicker & 1 & Flying \\
\hline Tree swallow & 2 & Flying \\
\hline Barn swallow & 13 & Flying \\
\hline Blue jay & 1 & Perched \\
\hline American crow & 6 & Flying \\
\hline Eastern bluebird & 2 & Perched \\
\hline Northern mockingbird & 3 & Perched, singing \\
\hline European starling & 10 & Feeding, ground \\
\hline Common yellowthroat & 3 & Perched, singing \\
\hline Blue grosbeak & 1 & Perched, singing \\
\hline Grasshopper sparrow & 17 & Perched, singing \\
\hline Bobolink & 2 & Perched, singing \\
\hline Eastern meadowlark & $\begin{array}{r}35 \\
2\end{array}$ & $\begin{array}{l}\text { Perched, singing } \\
\text { Flying }\end{array}$ \\
\hline Red-winged blackbird & 5 & Perched \\
\hline Brown-headed cowbird & 1 & Feeding, ground \\
\hline & 2 & Flying \\
\hline Common grackle & 5 & Flying \\
\hline American goldfinch & 4 & Flying \\
\hline
\end{tabular}

elsewhere. Tree swallows and barn swallows were abundant in August. Their increase in number may be related to the presence of young hatched during the year. The purple martin (Progne subis) was the most numerous species recorded. No martins were observed during the June survey. The large number of martins found in August is probably related to the addition of young of the year into the population and 
TABLE 6. Number and Species of Birds Observed on M-Field on August 14 and 15, 1991

\begin{tabular}{lccl}
\multicolumn{1}{c}{ Species } & No. Observed & & \multicolumn{1}{c}{ Activity } \\
Green-backed heron & 2 & & Flying \\
Great egret & 1 & & Flying \\
Great blue heron & 1 & & Flying \\
Canada goose & 10 & Feeding, ground \\
Turkey vulture & 3 & Flying \\
Bald eagle & 1 & Flying \\
Red-tailed hawk & 4 & Flying \\
Osprey & 2 & Flying \\
& 1 & Perched \\
American kestrel & 2 & Perched \\
Ring-necked pheasant & 1 & Standing, ground \\
Mourning dove & 8 & On ground \\
Eastern kingbird & 2 & Perched \\
Tree swallow & 69 & Flying \\
Purple martin & 105 & Flying \\
& 20 & Perched \\
Barn swallow & 72 & Flying \\
American crow & 14 & Flying \\
Eastern bluebird & 12 & Perched \\
Blue grosbeak & 1 & Perched, singing \\
Grasshopper sparrow & 6 & Perched, singing \\
Bobolink & 1 & Perched, singing \\
Eastern meadowlark & 20 & Perched, singing \\
& 2 & Flying \\
American goldfinch & 5 & Flying
\end{tabular}

perhaps a pre-migratory staging on M-Field. Twelve eastern bluebirds were also observed during August, while only two were observed in June. In June, the bluebirds were nesting and were more secretive; also, the young had not hatched or fledged. The August increase reflects the addition of young birds into the population. Bluebird houses were found in several areas around M-Field. These houses no doubt attracted the bluebirds to the area. One subadult bald eagle was observed flying over Mi-Field. Ten observations of Canada geese (Branta canadensis) were made. A small group of three birds was seen feedir.g on M-Field each day of the field study. Table 6 
provides a list of birds observed on M-Field during the August field studies.

\section{REPTILES AND AMPHIBIANS}

During the course of conducting the small mammal trapping, bird surveys, and other field work, we kept records of all reptiles and amphibians observed. The only snake observed was the common garter snake (Thamnophis sirtalis). One specimen was observed near plot 5ME in August. The only other reptile observed was a roadkilled wood turtle (Clemmys insculpta). The turtle was found during the June field trip, on the road near the tree farm (Figure 1) at the northwest corner of M-Field. Three amphibians were found on M-Field. The green frog (Rana clamitans), leopard frog (Rana pipiens), and Fowler's toad (Bufo woodhousei fowleri) were all observed during the June visit to M-Field. Leopard frogs were observed again during the August visit. Of interest were the captures of several green frogs in the small mammal traps. The dark cavity of the traps probably attracted the frogs during the hot, sunny days. Frogs may also have been attracted to small insects that often entered the traps to feed on the bait.

\section{INVERTEBRATES}

The average abundance of invertebrates collected from transects in the three treatment areas is shown in Table 7. The average abundance was slightly greater for the control area $(66.4 \pm 18.2)$ than for the exposed and unexposed mowed areas (60.8 \pm 17.4 and $53.0 \pm 11.6$, respectively), but the values were not significantly different $(\alpha=0.05)$. Nor were there any statistical differences detected for the diversity $\left(H^{\prime}\right)$, richness $(S)$, or evenness indices $\left(J^{\prime}\right)$ as shown in Table 7. 
TABLE 7. Between Plot Comparisons for Invertebrates Collected at M-Field

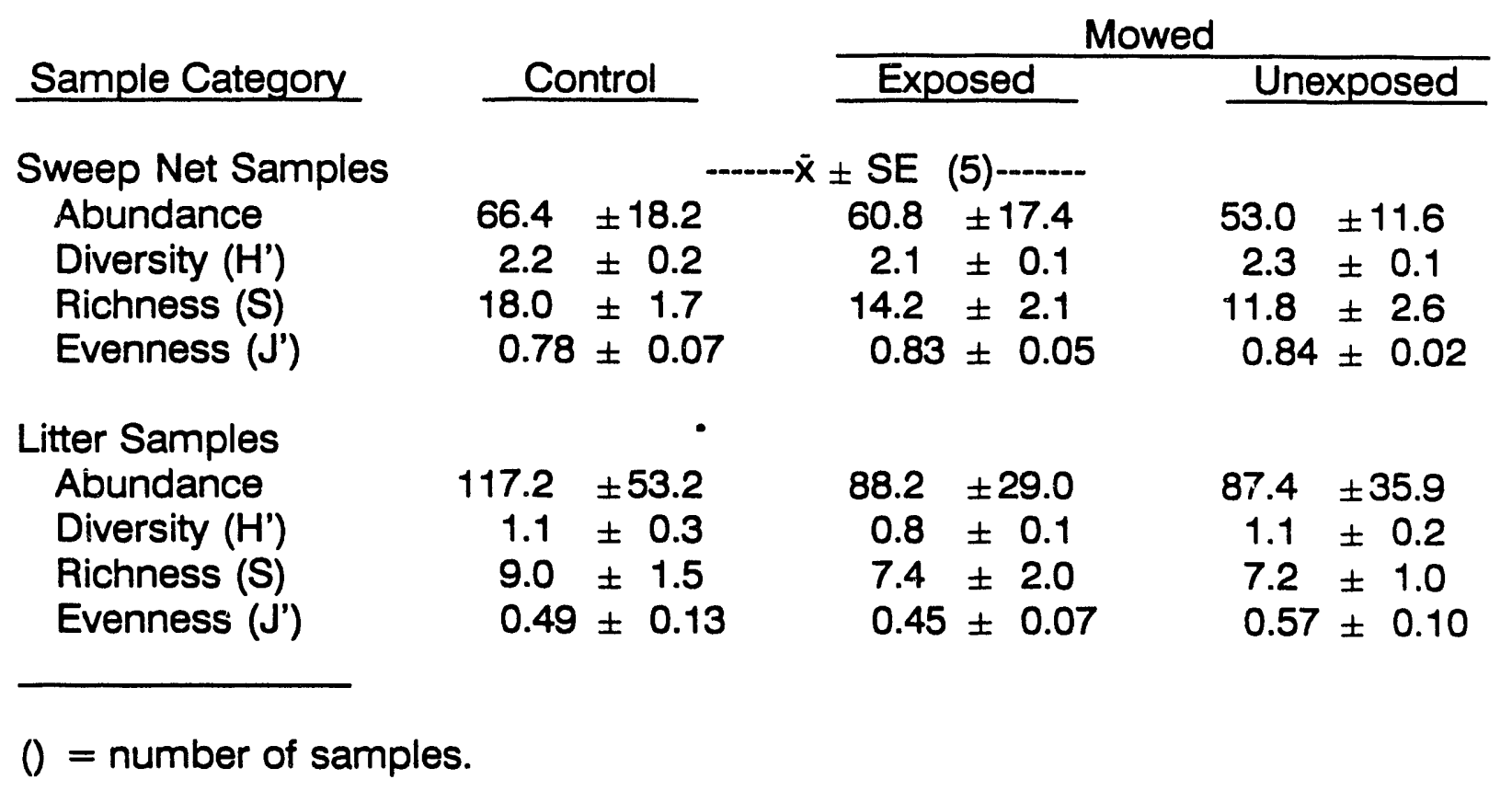

\section{Sweep Net Samples}

The abundance of invertebrate taxa collected in the sweep-net samples are shown in Table 8. The insect order Diptera (flies) was well represented in the collections with a total of 21 different families collected across the three treatments. The Syrphidae and Chloropidae were consistently collected in most transects.

Leafhoppers (Cicadellidae) and aphids were also abundant and consistently collected. Orthopterans as represented by both long-horned (Tettigoniidae) and short-horned grasshoppers (Acrididae) were commonly collected with no noticeable distribution across the study transects.

\section{Litter Samples}

The average abundance of litter inhabitants collected from the three treatment areas is shown in Table 7. The average abundance for the control transects was somewhat higher than for the mowed treatments, but none of the values for the three areas were significantly different $(\alpha=0.05)$. The diversity $\left(H^{\prime}\right)$, richness $(S)$, and 


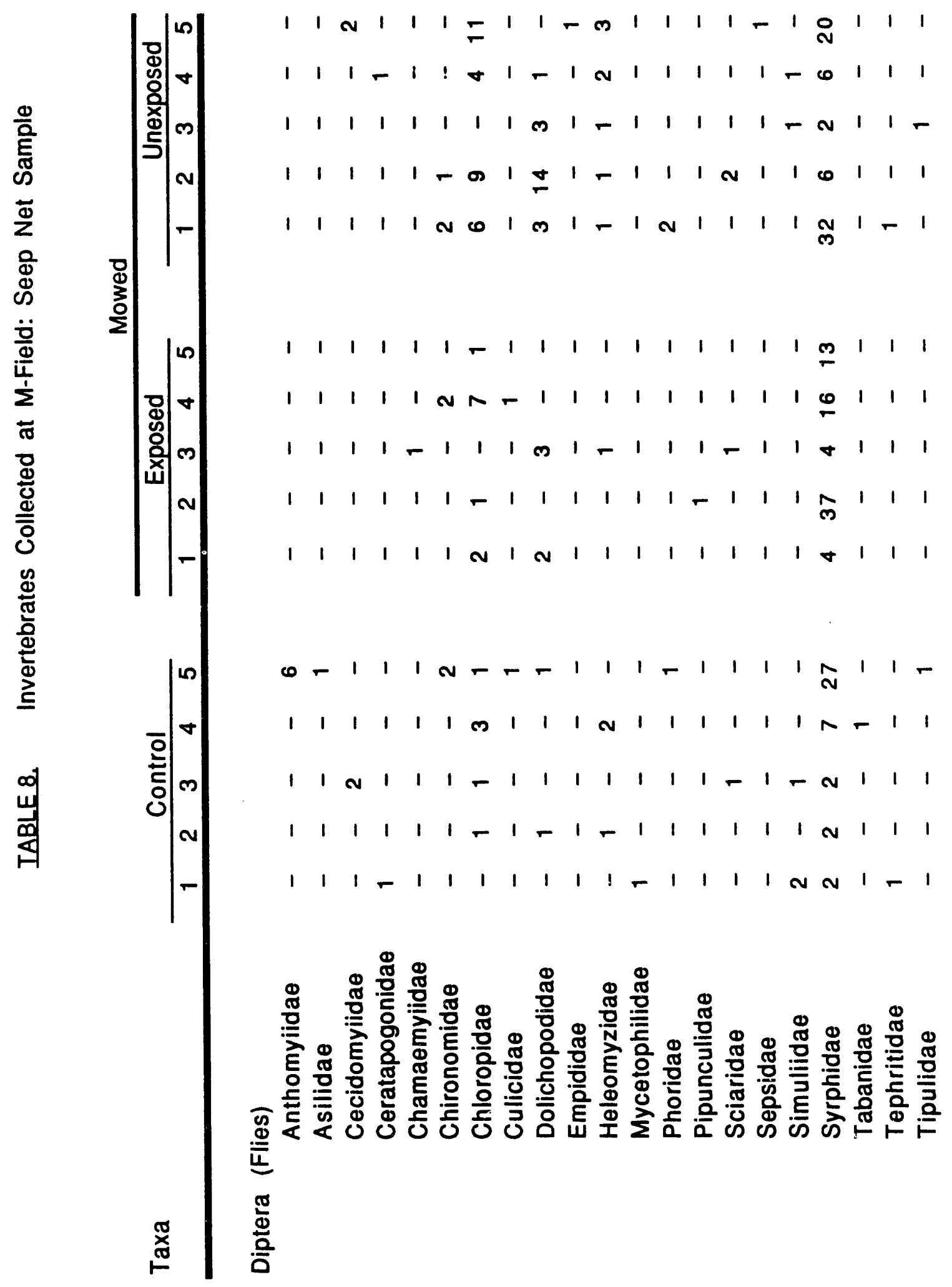




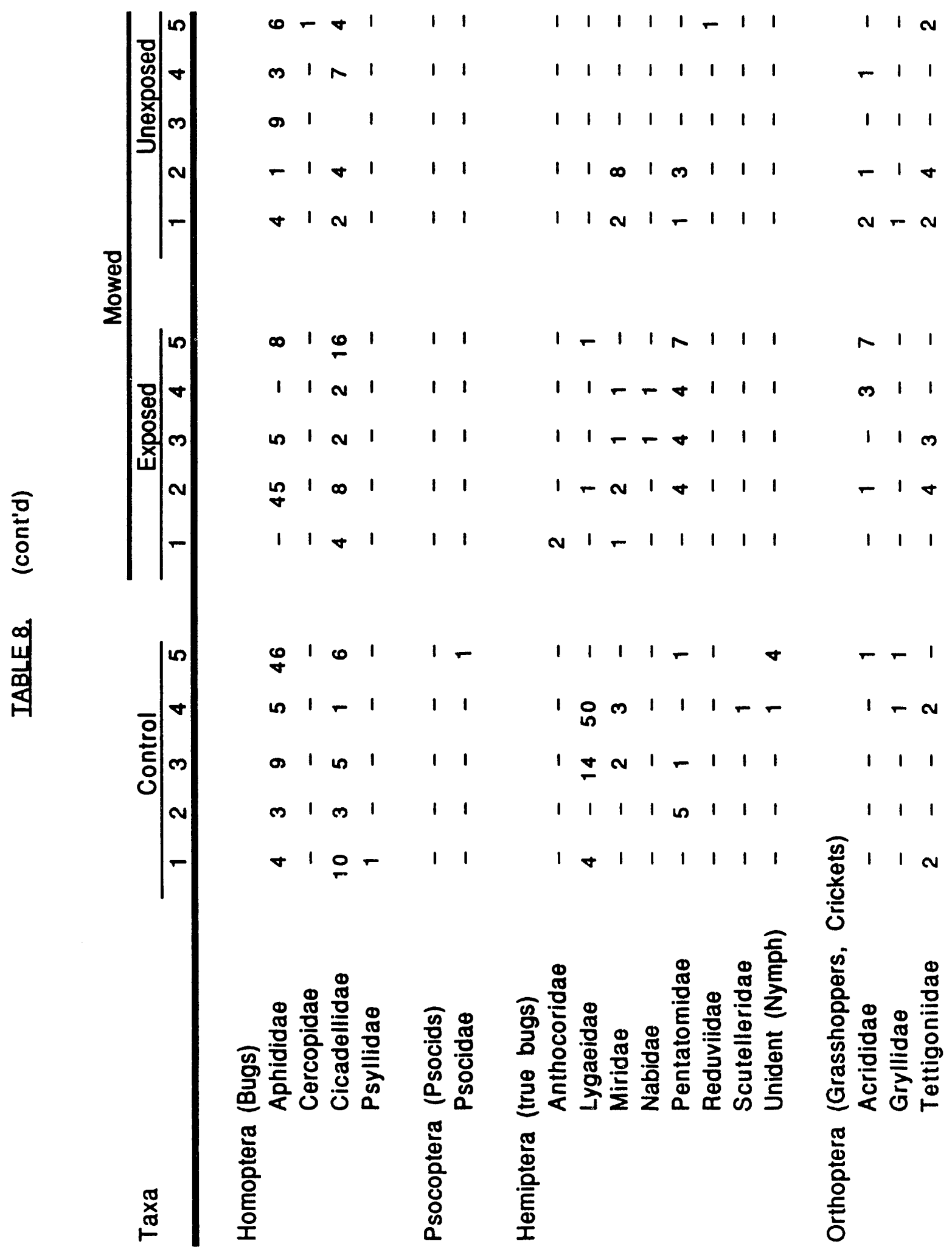




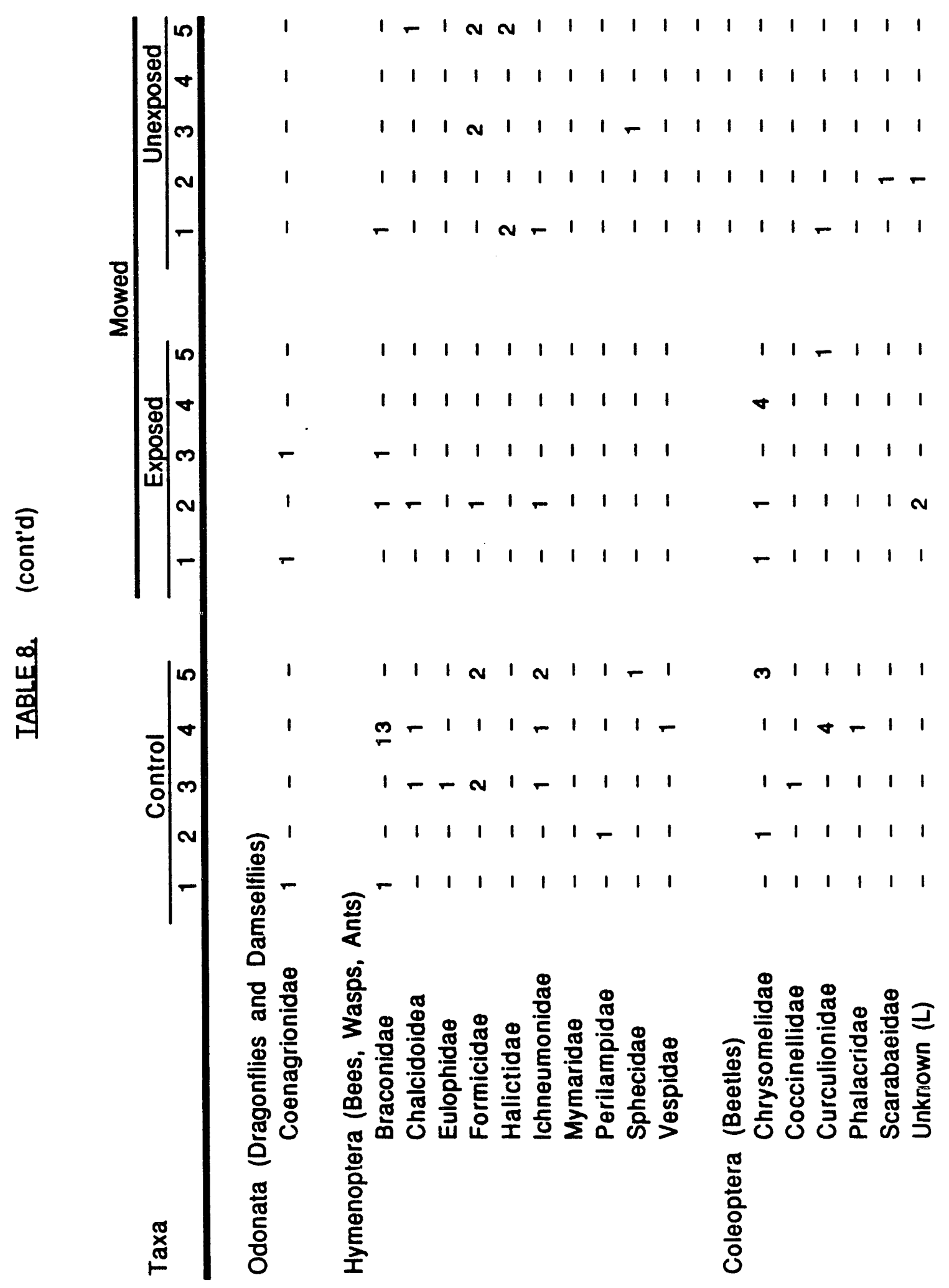




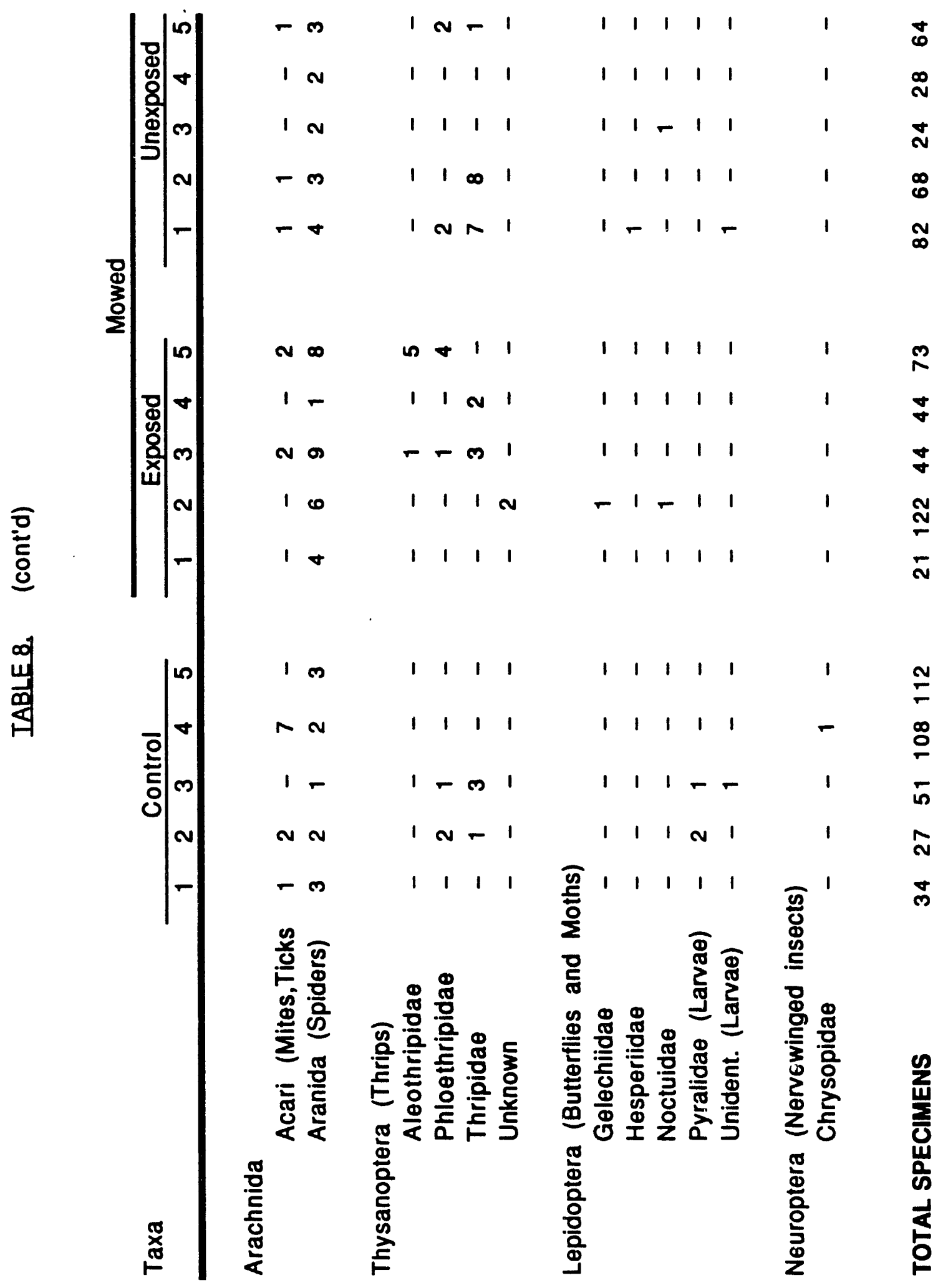


evenness indices are also shown in Table 7 for the litter samples. There were no significant differences between any of the values $(\alpha=.05)$.

The abundance of invertebrate taxa collected from the litter layer is shown in Table 9. The Acari (mites) were collected from every transect. They were also the most abundant taxa collected. The Collembola (springtails) were collected from all but two transects and were also an abundant part of the invertebrate fauna. 


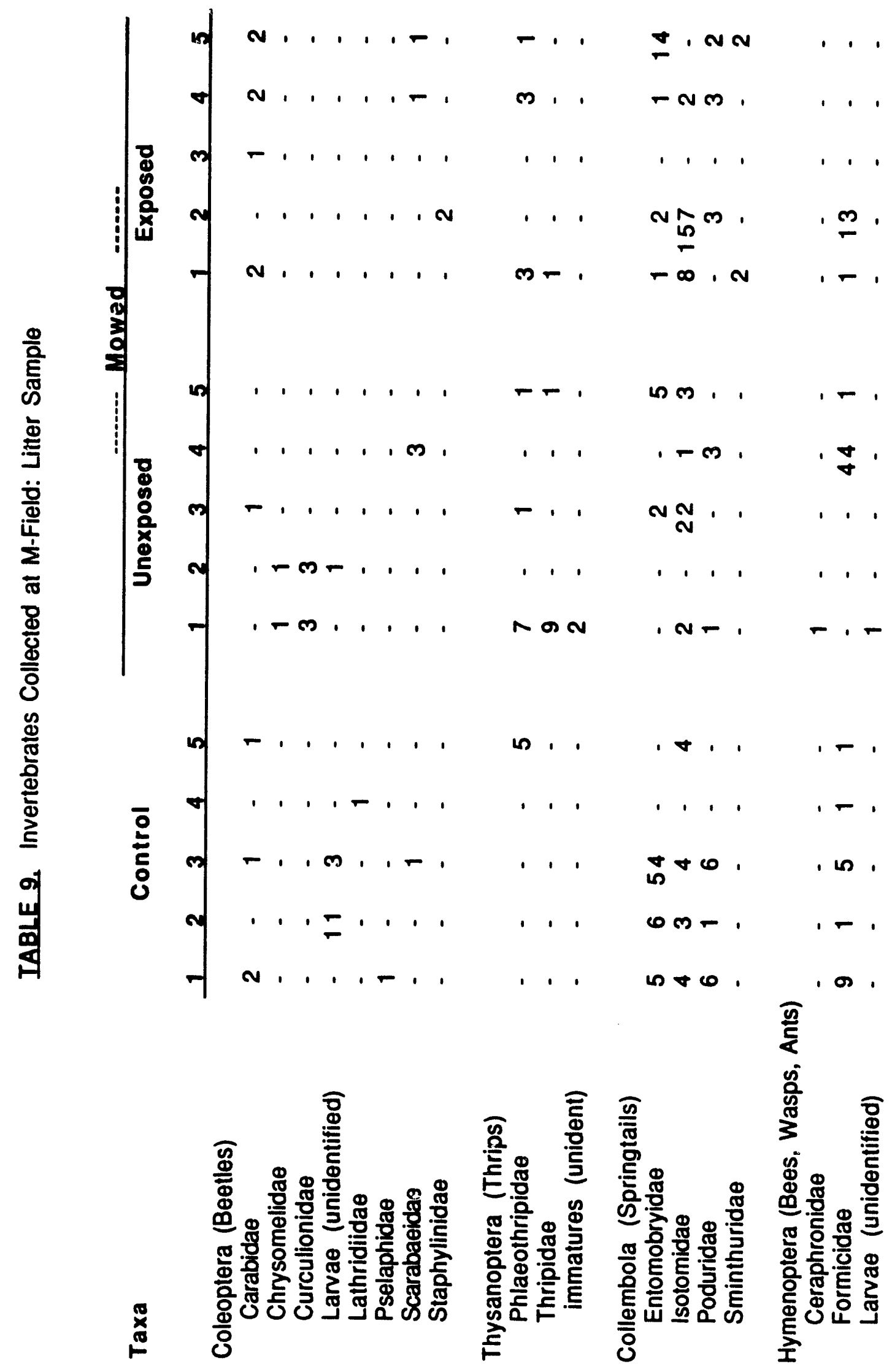




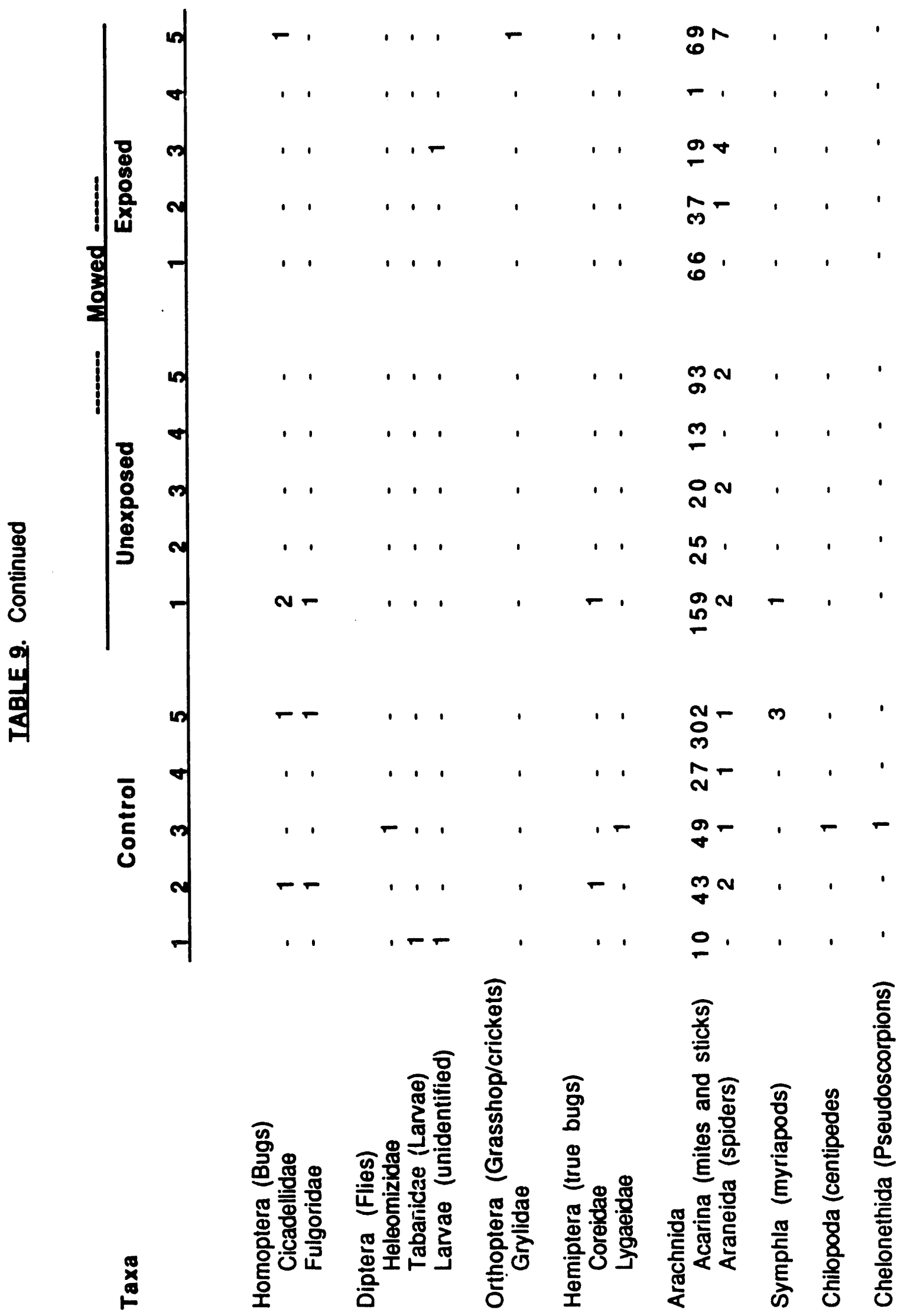




\section{CONCLUSIONS}

The M-Field area supports diverse wildlife and vegetation. No significant biological effects of testing smokes and obscurants could be detected in our survey. Differences in canopy cover and small mammal abundance appeared to be related to mowing of the field and disturbance from vehicle traffic rather than chronic exposure to smokes. The use of the M-Field area by the bald eagle, an endangered species, is of interest; however, bald eagles are unlikely to use M-Fiald during testing of smokes and obscurants because of the number of people and the activities associated with testing. Bald eagles were present on M-Field to take advantage of a food source (red fox carcass) and are not expected to use the area under most circumstances.

Mowed areas were attractive to swallows and other aerial feeders. Fewer bird species were observed in August than in June, but the total number of birds using the area was higher. The increase in number of birds is probably related to the addition of young of the year into the population.

A total of 76 families of invertebrates were collected from the M-Field sampling areas. There were no significant differences in invertebrate abundance between mowed and unmowed areas. Although the average abundance was slightly higher on the unmowed unexposed transects, the difference was not significant.

Detection of any chronic biological effects as a result of testing activities would require regular monitoring of the flora and fauna over several seasons. 


\section{REFERENCES}

Borror, D. J., D. M. DeLong, and C. A. Tripplehorn. 1976. An Introduction to the Study of Insects. Holt, Rinehart and Winston. New York.

Chu, H. F. 1949. How to Know the Immature Insects. Wm C. Brown Co. Dubuque, lowa.

Daubenmire, R. 1959. "A Canopy Cover Method of Vegetation Analysis." Northwest Sci. 33:43-64.

Miller, R. G. Jr. 1966. Simultaneous Statistical Inference. McGraw-Hill Book Co. New York. 272 pp.

Pielou, E. C. 1969. An Introduction to Mathematical Ecology. Wiley-Inter Science, New York.

Shannon, C., and W. Weaver. 1949. The Mathematical Theory of Communication. University of Illinois Press, Chicago. 117 pp.

Steel, R., and J. H. Torrie. 1980. Principles and Procedures of Statistics: A Biometrical Approach. McGraw-Hill Book Company, New York. 
APPENDIX A

COORDINATES OF SAMPLING TRANSECTS ON M-FIELD 
IABLEA.1. Locations of Sampling Transects on M Field (given in Universal Transverse Mercator System Grid Coordinates)

Transect Location

$1 \mathrm{MU}$
$2 \mathrm{MU}$
$3 \mathrm{MU}$
$4 \mathrm{MU}$
$5 \mathrm{MU}$
$1 \mathrm{ME}$
$2 \mathrm{ME}$
$3 \mathrm{ME}$
$4 \mathrm{ME}$
$5 \mathrm{ME}$
1
2
3
4
5

Starting Location

Easting Northing

$388539 \quad 4356872$

$388398 \quad 4357190$

$388403 \quad 4357087$

$388420 \quad 4356934$

$388460 \quad 4357091$

$388516 \quad 4356718$

$388558 \quad 4356458$

$388541 \quad 4356385$

$388653 \quad 4356751$

$386592 \quad 4356668$

$388885 \quad 4356383$

$388846 \quad 4356433$

$388815 \quad 4357160$

$388782 \quad 4356862$

388768

4357049
Ending Location

Easting Northing

$388523 \quad 4356825$

$388450 \quad 4357189$

$388394 \quad 4357035$

$388466 \quad 4356948$

$388412 \quad 4377086$

$388532 \quad 4306672$

$388610 \quad 4356463$

$388547 \quad 4356330$

$388599 \quad 4356744$

$388589 \quad 4356719$

$388893 \quad 4356334$

$388814 \quad 4356443$

$388823 \quad 4357112$

$388831 \quad 4356869$

$388782 \quad 4356987$ 


\section{APPENDIX B}

MEASUREMENT OF PERCENT COVER VEGETATION ON M-FIELD TRANSECTS 
TABLE B.1. Estimates of Vegetation Canopy Cover on Unmowed, Unexposed Transects (1-5) in June

Transect 1

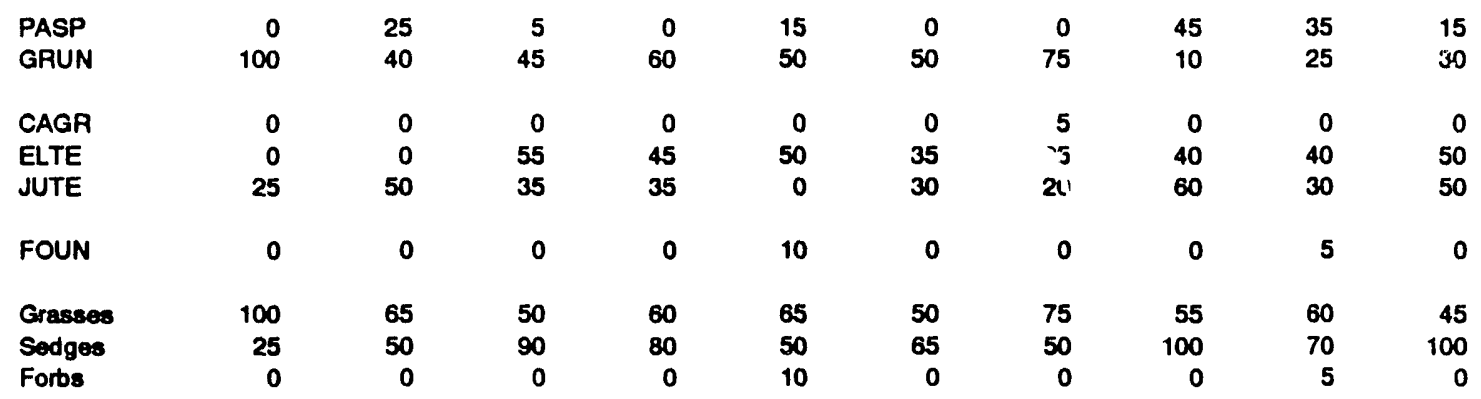

Transect 2

ANAR

HOLA

PASP

GRUN

$\begin{array}{rrr}3 & 20 & \\ 0 & 8 & \\ 5 & 40 & 5 \\ 100 & 40 & 45\end{array}$

0
0
5
45

$\begin{array}{rr}10 & 0 \\ 0 & 0 \\ 6 & 5 \\ 60 & 50\end{array}$

ELTE

0

JUTE

$\begin{array}{rrr}0 & 0 & 15 \\ 0 & 10 & 25\end{array}$

0
35

POSP

SCIN

PAQU

CAFA

FOUN

Grasses

Sedges

Forbs

0
0
0
0
7

$25 \quad 25$

$\begin{array}{rrr}0 & 0 & 0 \\ 0 & 0 & 0 \\ 0 & 0 & 0 \\ 50 & 75 & 10\end{array}$

$\begin{array}{lrr}0 & 0 & 0 \\ 0 & 0 & 5 \\ 0 & 0 & 0\end{array}$

Transect 3

ANAR

PASP

GRUN

$\begin{array}{rr}5 & 5 \\ 17 & 10 \\ 10 & 50\end{array}$

$\begin{array}{rrr}0 & 25 & 40 \\ 7 & 20 & 0 \\ 60 & 50 & 45\end{array}$

20

ELTE

JUSP

$30 \quad 10 \quad 10$

JUTE

LASP

POSP

SCIN

VISP

FOUN

Grasses

Sedges

Forbs

Transect 4

ANAR

HOLA

PASP

GRUN

$\begin{array}{rr}1 & 0 \\ 20 & 0 \\ 8 & 7 \\ 25 & 85\end{array}$

$\begin{array}{rl}0 & 0 \\ 0 & 0 \\ 7 & 0 \\ 85 & 0\end{array}$

0
0
6
40

0
10
3
35

10
12
0
78

0
0
20
5

5
0
0
70

$\begin{array}{rr}0 & 0 \\ 0 & 0 \\ 0 & 0 \\ 45 & 35\end{array}$

B.1 
TABLE B.1. cont.

\begin{tabular}{|c|c|c|c|c|c|c|c|c|c|c|}
\hline CAAN & 0 & 8 & 3 & 10 & 3 & 0 & 25 & 0 & 18 & 0 \\
\hline ELTE & 0 & 7 & 80 & 0 & 0 & 0 & 40 & 0 & 0 & 0 \\
\hline JUTE & 10 & 12 & 0 & 60 & 16 & 8 & 10 & 30 & 0 & 55 \\
\hline PEDI & 50 & 5 & 30 & 0 & 10 & 0 & 0 & 0 & 0 & 0 \\
\hline POSP & 40 & 15 & 0 & 0 & 0 & 0 & 0 & 0 & 5 & 0 \\
\hline SCIN & 0 & 0 & 0 & 0 & 12 & 0 & 0 & 0 & 0 & 0 \\
\hline SIAR & 4 & 0 & 20 & 5 & 0 & 0 & 0 & 3 & 0 & 0 \\
\hline FOUN & 12 & 18 & 0 & 0 & 0 & 25 & 5 & 8 & 8 & 0 \\
\hline Grasses & 54 & 92 & 0 & 46 & 48 & 100 & 25 & 75 & 45 & 45 \\
\hline Sedges & 10 & 27 & 83 & 70 & 19 & 8 & 75 & 30 & 18 & 55 \\
\hline Forbs & 56 & 38 & 50 & 5 & 22 & 25 & 5 & 11 & 13 & 0 \\
\hline
\end{tabular}

Traneect 5

\begin{tabular}{|c|c|c|c|c|c|c|c|c|c|c|}
\hline ANAR & 45 & 25 & 6 & 12 & 5 & 10 & 10 & 20 & 6 & 33 \\
\hline HOLA & 0 & 0 & 0 & 0 & 0 & 0 & 0 & 10 & 30 & 7 \\
\hline PASP & 0 & 0 & 12 & 5 & 3 & 0 & 5 & 0 & 0 & 0 \\
\hline GRUN & 50 & 50 & 65 & 90 & 90 & 100 & 95 & 80 & 80 & 70 \\
\hline CAGR & 0 & 0 & 0 & 0 & 0 & 5 & 1 & 5 & 0 & 0 \\
\hline CASQ & 0 & 0 & 0 & 0 & 1 & 0 & 0 & 0 & 0 & 0 \\
\hline JUTE & 0 & 0 & 3 & 3 & 8 & 1 & 3 & 15 & 0 & 0 \\
\hline PAQU & 0 & 0 & 0 & 0 & 0 & 0 & 0 & 0 & 0 & 5 \\
\hline DACA & 4 & 0 & 0 & 0 & 0 & 0 & 0 & 0 & 0 & 0 \\
\hline LASP & 0 & 0 & 0 & 0 & 0 & 0 & 5 & 0 & 0 & 0 \\
\hline OXSP & 0 & 0 & 0 & 0 & 3 & 0 & 0 & 3 & 0 & 5 \\
\hline PEDI & 0 & 7 & 0 & 0 & 0 & 0 & 0 & 0 & 0 & 0 \\
\hline PLLA & 7 & 13 & 0 & 0 & 0 & 0 & 0 & 0 & 0 & 0 \\
\hline POSP & 0 & 0 & 15 & 0 & 3 & 10 & 0 & 10 & 0 & 0 \\
\hline SCIN & 5 & 0 & 0 & 0 & 0 & 0 & 0 & 0 & 0 & 0 \\
\hline CAFA & 25 & 0 & 0 & 0 & 0 & 0 & 0 & 10 & 0 & 0 \\
\hline FOUN & 15 & 26 & 20 & 18 & 20 & 0 & 10 & 12 & 20 & 38 \\
\hline Grasses & 95 & 75 & 83 & 107 & 98 & 110 & 110 & 110 & 116 & 110 \\
\hline Sediges & 0 & 0 & 3 & 3 & 9 & 6 & 4 & 20 & 0 & 0 \\
\hline Forbs & 56 & 46 & 35 & 18 & 26 & 10 & 15 & 35 & 20 & 48 \\
\hline
\end{tabular}


TABLE B.2. Estimates of Vegetation Canopy Cover on Mowed, Exposed Transects (IME-5ME) in June

\begin{tabular}{|c|c|c|c|c|c|c|c|c|c|c|}
\hline \multicolumn{11}{|c|}{ Transect 1-ME } \\
\hline ANAR & $\begin{array}{r}10 \\
0\end{array}$ & & 5 & 0 & 5 & 0 & 5 & 0 & 0 & 0 \\
\hline HOLA & $\begin{array}{r}0 \\
10\end{array}$ & $\begin{array}{r}10 \\
0\end{array}$ & 0 & 10 & 0 & 0 & 0 & 0 & 10 & 0 \\
\hline PASP & 10 & $\begin{array}{l}0 \\
0\end{array}$ & 5 & 0 & 0 & 0 & 0 & 0 & 0 & 0 \\
\hline ANO & 0 & 0 & 0 & 0 & 0 & & & & & \\
\hline JUTE & 30 & 0 & 20 & 10 & 3 & 0 & 10 & 30 & 15 & 25 \\
\hline GRUN & 65 & 15 & 50 & 75 & 50 & 60 & 5 & 0 & 70 & 50 \\
\hline OXSP & 0 & 0 & 2 & 0 & 0 & 0 & 0 & 0 & 15 & 0 \\
\hline PLLA & 0 & 50 & 0 & 45 & 30 & 0 & 0 & 10 & 0 & 40 \\
\hline POSp & 25 & 40 & 30 & 0 & 0 & 0 & 0 & 3 & 5 & 0 \\
\hline SCIN & 0 & 0 & 5 & 0 & 0 & 0 & 0 & 0 & 0 & 0 \\
\hline PAQU & 3 & 0 & 2 & 0 & 0 & 0 & 0 & 0 & 0 & 0 \\
\hline TRSP & 0 & 4 & 0 & 0 & 0 & 0 & 0 & 0 & 10 & 0 \\
\hline FOUN & 0 & 0 & 0 & 3 & 0 & 0 & 0 & 0 & 1 & 5 \\
\hline \multicolumn{11}{|c|}{ Transect 2-ME MOWED RECENTLY } \\
\hline ANAR & 10 & 10 & 10 & 0 & 0 & 0 & 0 & 0 & 0 & 10 \\
\hline ELTE & 0 & 4 & 0 & 0 & 0 & 0 & 0 & 0 & 0 & 0 \\
\hline JUTE & 15 & 0 & 0 & 0 & 10 & 0 & 0 & 0 & 0 & 0 \\
\hline PASP & 20 & 15 & 15 & 15 & 40 & 15 & 15 & 30 & 0 & 0 \\
\hline HOLA & 5 & 10 & 0 & 0 & 0 & 0 & 0 & 0 & 0 & 15 \\
\hline GUNK & 55 & 65 & 80 & 55 & 75 & 60 & 75 & 50 & 55 & 65 \\
\hline OXSP & 3 & 3 & 3 & 0 & 0 & 0 & 0 & 0 & 0 & 0 \\
\hline POSP & 20 & 3 & 0 & 0 & 0 & 12 & 15 & 15 & 20 & 10 \\
\hline SIAR & 1 & 0 & 0 & 0 & 0 & 0 & 0 & 0 & 0 & 0 \\
\hline FOUN & 30 & 50 & 8 & 48 & 17 & 5 & 3 & 22 & 14 & 40 \\
\hline \multicolumn{11}{|l|}{ Totals } \\
\hline Grasses & 90 & 100 & 105 & 70 & 115 & 75 & 90 & 80 & 55 & 75 \\
\hline Sedg• & 15 & 4 & 0 & 0 & 10 & 0 & 0 & 0 & 0 & 0 \\
\hline Forbs & 54 & 56 & 11 & 48 & 17 & 17 & 18 & 37 & 3450 & \\
\hline \multicolumn{11}{|c|}{ Transect 3.ME } \\
\hline ANAR & 10 & 0 & 20 & 20 & 10 & 40 & 5 & 65 & 5 & 0 \\
\hline HOLA & 10 & 20 & 40 & 30 & 30 & 0 & 10 & 5 & 0 & 0 \\
\hline JUTE & 0 & 10 & 0 & 15 & 20 & 5 & 65 & 10 & 0 & 20 \\
\hline PASP & 0 & 0 & 0 & 0 & 0 & 10 & 0 & 0 & 0 & 0 \\
\hline ELTE & 0 & 0 & 0 & 25 & 58 & 0 & 50 & 0 & 0 & 0 \\
\hline SONU & 5 & 0 & 0 & 0 & 0 & 0 & 0 & 0 & 0 & 0 \\
\hline GUNK & 80 & 70 & 60 & 25 & 30 & 70 & 60 & 65 & 95 & 100 \\
\hline DACA & 0 & 0 & 0 & 0 & 0 & 10 & 0 & 0 & 0 & 0 \\
\hline POSP & 15 & 5 & 10 & 0 & 20 & 25 & 0 & 0 & 10 & 0 \\
\hline FOUN & 12 & 5 & 10 & 35 & 15 & 0 & 0 & 12 & 5 & 1 \\
\hline \multicolumn{11}{|l|}{ Totabs } \\
\hline Grasses & 105 & 90 & 120 & 75 & 70 & 120 & 75 & 135 & 100 & 100 \\
\hline Sedges & 0 & 10 & 0 & 40 & 78 & 5 & 115 & 10 & 0 & 20 \\
\hline Forbs & 27 & 10 & 20 & 35 & 35 & 35 & 0 & 12 & 15 & 1 \\
\hline
\end{tabular}

Transect 4-ME

\begin{tabular}{|c|c|c|c|c|c|c|c|c|c|c|}
\hline HOLA & 3 & 0 & 0 & 0 & 0 & 0 & 0 & 0 & 0 & 0 \\
\hline JUTE & 0 & 15 & 0 & 0 & 0 & 15 & 0 & 20 & 50 & 60 \\
\hline PASP & 0 & 0 & 0 & 0 & 0 & 0 & 13 & 15 & 5 & 10 \\
\hline GUNK & 40 & 35 & 85 & 85 & 80 & 75 & 80 & 85 & 55 & 35 \\
\hline DACA & 3 & 0 & 0 & 0 & 0 & 4 & 0 & 0 & 0 & 0 \\
\hline OXSP & 0 & 0 & 5 & 0 & 0 & 0 & 0 & 0 & 0 & 0 \\
\hline
\end{tabular}


TABLE B.2. cont.

\begin{tabular}{|c|c|c|c|c|c|c|c|c|c|c|}
\hline SIAR & 0 & 3 & 0 & 0 & 0 & 0 & 0 & 0 & 0 & 0 \\
\hline TRSP & 60 & 75 & 0 & 0 & 0 & 0 & 0 & 0 & 0 & 0 \\
\hline \multicolumn{11}{|l|}{ Totals } \\
\hline Grasses & 43 & 35 & 85 & 85 & 80 & 75 & 93 & 100 & 60 & 45 \\
\hline Sedges & 0 & 15 & 0 & 0 & 0 & 15 & 0 & 20 & 50 & 60 \\
\hline Forbs & 63 & 78 & 5 & 0 & 0 & 4 & 0 & 0 & 0 & 0 \\
\hline
\end{tabular}

Transect 5-ME

$\begin{array}{lrrrrrrrrrr}\text { ANAR } & 2 & 40 & 0 & 2 & 10 & 90 & 60 & 30 & 25 & 45 \\ \text { CAAN } & 0 & 0 & 0 & 0 & 0 & 0 & 0 & 0 & 3 & 0 \\ \text { HOLA } & 0 & 0 & 0 & 0 & 0 & 0 & 0 & 0 & 40 & 30 \\ \text { JUTE } & 20 & 25 & 20 & 10 & 10 & 15 & 10 & 50 & 5 & 20 \\ \text { PASP } & 15 & 20 & 0 & 3 & 30 & 2 & 40 & 12 & 10 & 15 \\ \text { ELTE } & 0 & 0 & 0 & 85 & 90 & 20 & 0 & 0 & 10 & 25 \\ \text { GUNK } & 60 & 50 & 50 & 70 & 25 & 30 & 20 & 30 & 0 & 30 \\ \text { POSP } & 0 & 0 & 0 & 0 & 0 & 0 & 0 & 0 & 30 & 0 \\ \text { SCIN } & 0 & 0 & 0 & 0 & 0 & 0 & 0 & 0 & 3 & 20 \\ \text { SIAR } & 0 & 0 & 0 & 0 & 0 & 0 & 3 & 40 & 0 & 0 \\ \text { FOUN } & 0 & 0 & 0 & 0 & 0 & 0 & 0 & 0 & 30 & 0\end{array}$

Totals

Grasses

Sedges

$\begin{array}{rrrrr}75 & 70 & 50 & 74 & 55 \\ 80 & 75 & 70 & 80 & 35 \\ 0 & 0 & 0 & 0 & 0\end{array}$

$\begin{array}{rr}50 & 60 \\ 45 & 30 \\ 0 & 3\end{array}$

$\begin{array}{rrr}42 & 51 & 75 \\ 80 & 8 & 50 \\ 40 & 63 & 20\end{array}$


TABLE B.3. Estimates of Vegetation Canopy Cover on Mowed Unexposed Transects (IMU-5MU) in June

\begin{tabular}{|c|c|c|c|c|c|c|c|c|c|c|}
\hline \multicolumn{11}{|c|}{ Transect $1-M U$} \\
\hline HOLA & 4 & 10 & 17 & 0 & 0 & 0 & 0 & 0 & 0 & $\mathbf{0}$ \\
\hline PASP & 0 & 0 & 15 & 5 & 0 & 20 & 0 & 0 & 0 & 15 \\
\hline SEGE & 0 & 5 & 0 & 0 & 0 & 0 & 0 & 0 & 0 & 0 \\
\hline GRUN & 65 & 20 & 45 & 75 & 60 & 50 & 70 & 55 & 95 & 75 \\
\hline DACA & 0 & 0 & 0 & 0 & 7 & 0 & 0 & 0 & 0 & 0 \\
\hline OXAP & 5 & 5 & 5 & 0 & 0 & 0 & 0 & 0 & 0 & 0 \\
\hline PLLA & 0 & 10 & 15 & 15 & 15 & 20 & 35 & 10 & 0 & 5 \\
\hline POSP & 0 & 5 & 0 & 3 & 3 & 0 & 20 & 30 & 0 & 0 \\
\hline RASP & 0 & 2 & 0 & 0 & 0 & 0 & 0 & 0 & 0 & 0 \\
\hline TRSP & 0 & 0 & 0 & 0 & 20 & 65 & 0 & 0 & 3 & 0 \\
\hline FOUN & 15 & 15 & 0 & 5 & 10 & 0 & 3 & 0 & 8 & 10 \\
\hline \multicolumn{11}{|l|}{ Totals } \\
\hline Grassers & 75 & 42 & 60 & 80 & 60 & 70 & 70 & 55 & 95 & 90 \\
\hline \multicolumn{11}{|l|}{ Sedge } \\
\hline Forb & 20 & 37 & 20 & 23 & 55 & 85 & 58 & 40 & 11 & 15 \\
\hline \multicolumn{11}{|c|}{ Transect 4-MU } \\
\hline PASP & 25 & 0 & 10 & 15 & 0 & 0 & 3 & 35 & 0 & 5 \\
\hline ANAR & 0 & 0 & 0 & 0 & 25 & 0 & 0 & 10 & 5 & 40 \\
\hline GRUN & 5 & 70 & 25 & 40 & 15 & 90 & 90 & 50 & 3 & 7 \\
\hline POSP & 0 & 0 & 0 & 0 & 3 & 0 & 0 & 0 & 1 & 0 \\
\hline SOCA & 0 & 0 & 0 & 0 & 0 & 3 & 0 & 0 & 0 & 0 \\
\hline FOUN & 10 & 15 & 4 & 4 & 27 & 10 & 8 & 3 & 1 & 30 \\
\hline \multicolumn{11}{|l|}{ Totals } \\
\hline $\begin{array}{l}\text { Grasses } \\
\text { Sedges }\end{array}$ & 30 & 70 & 35 & 55 & 40 & 90 & 93 & 95 & 8 & 52 \\
\hline Forbs & 10 & 15 & 4 & 4 & 30 & 13 & 8 & 3 & 2 & 30 \\
\hline
\end{tabular}




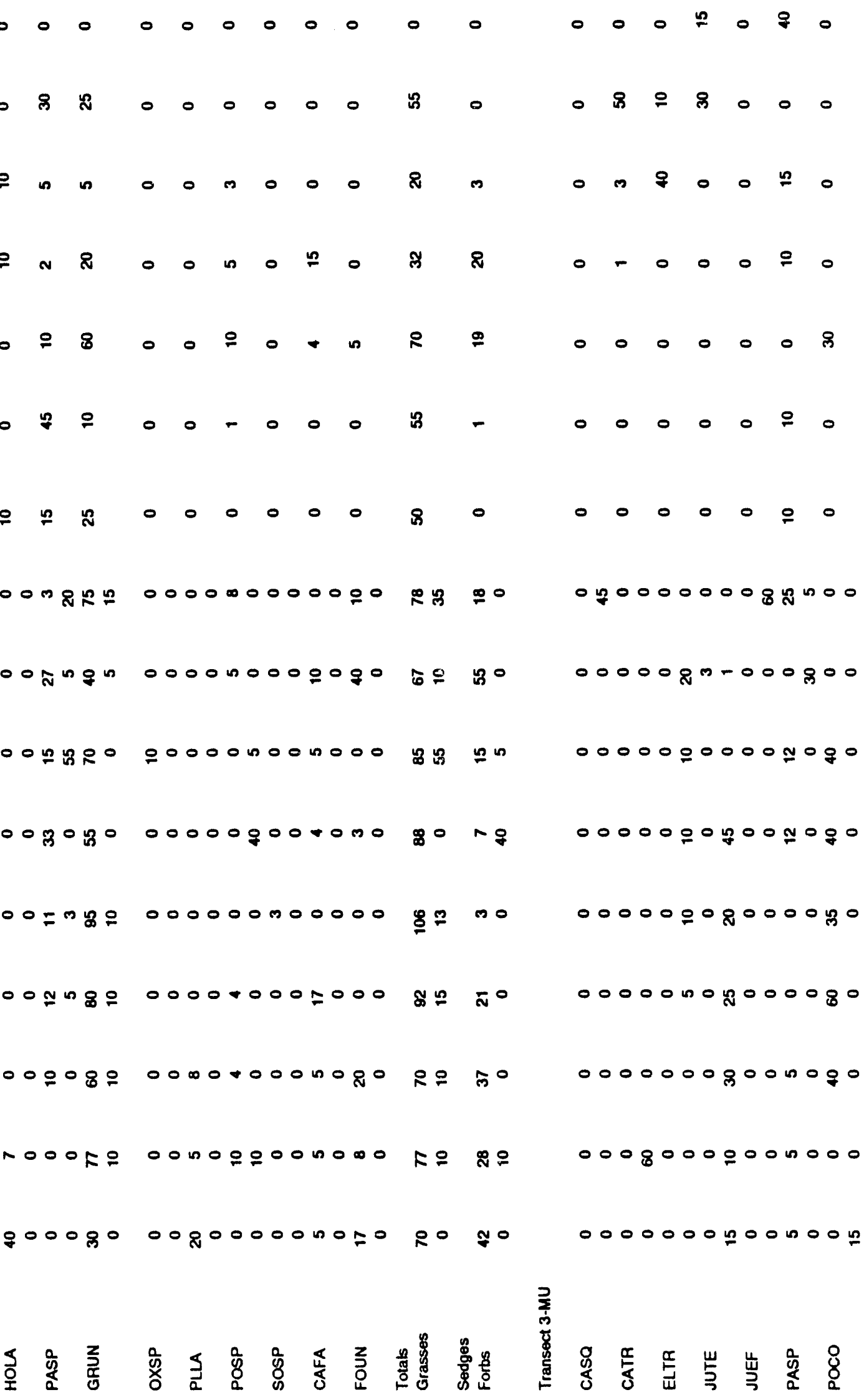




$$
\begin{aligned}
& \text { R } 00000000000
\end{aligned}
$$

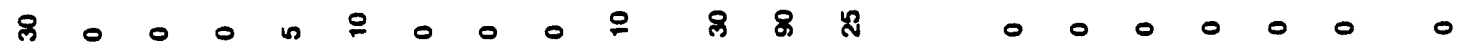

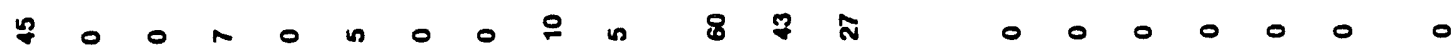

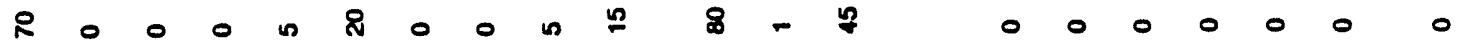

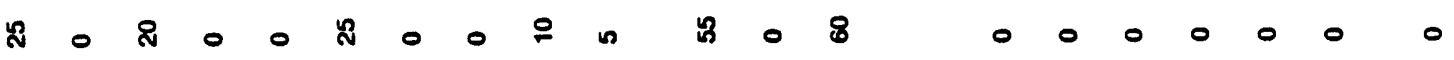

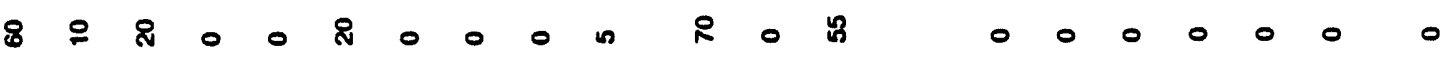

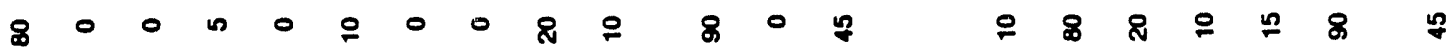

$$
\begin{aligned}
& \text { B } 500000000800000 \text { N } \\
& \text { Dho } \\
& 88000000 \text { 응 } \\
& \text { S2 }
\end{aligned}
$$

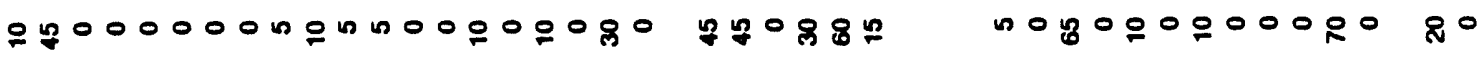

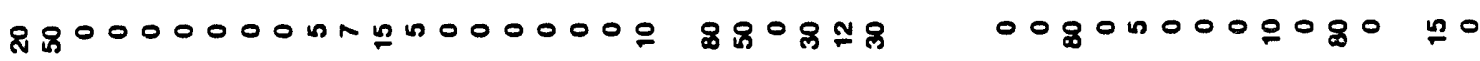

$$
\begin{aligned}
& \text { \& } \\
& 880000000000000000 \text { N } 880 R N 2 \quad-0800000008000 \\
& \text { 통 }
\end{aligned}
$$

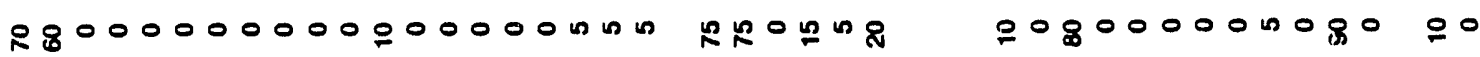

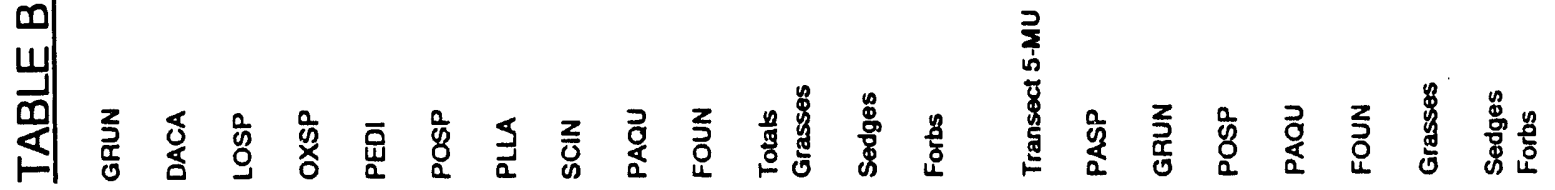$$
\text { लं }
$$ 
TABLE B.4. Estimates of Vegetation Canopy Cover on Unmowed, Unexposed Transects (1-5) in August

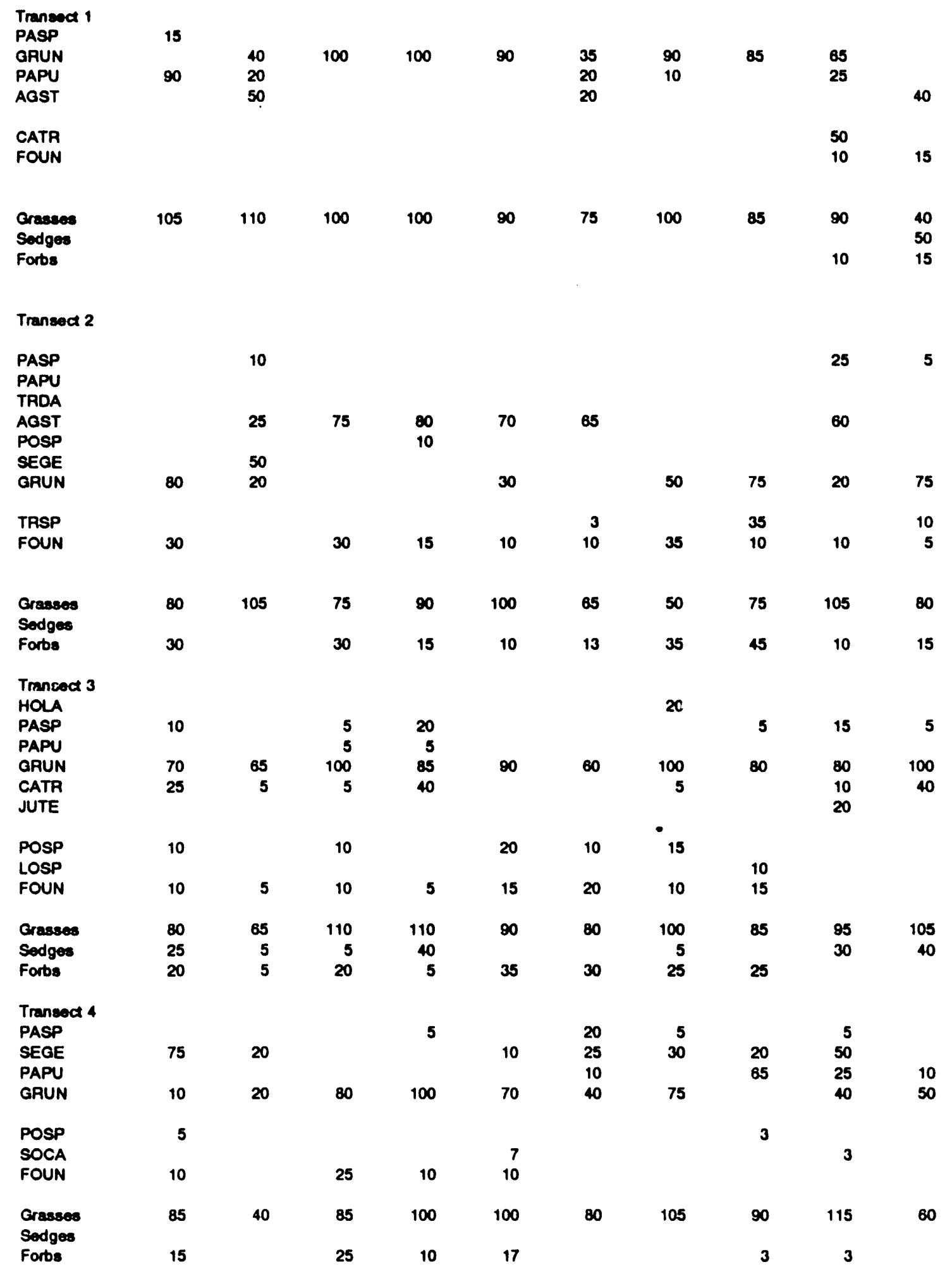


TABLE B.4. cont.

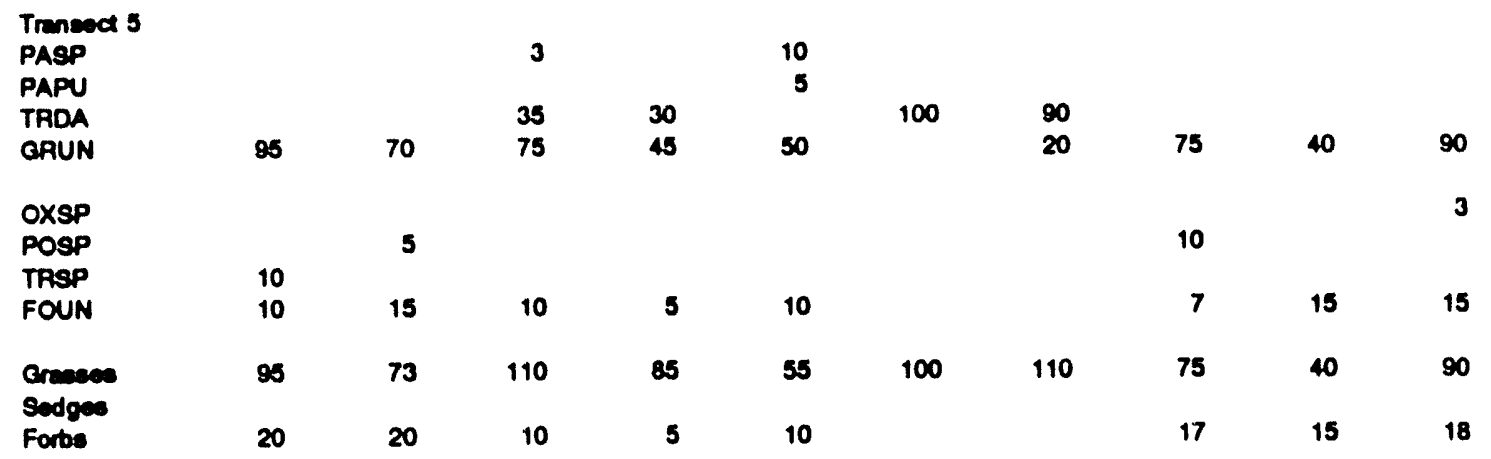


TABLE B.5. Estimates of Vegetation Canopy Cover on Mowed, Unexposed Transects (IMU-5MU) in August

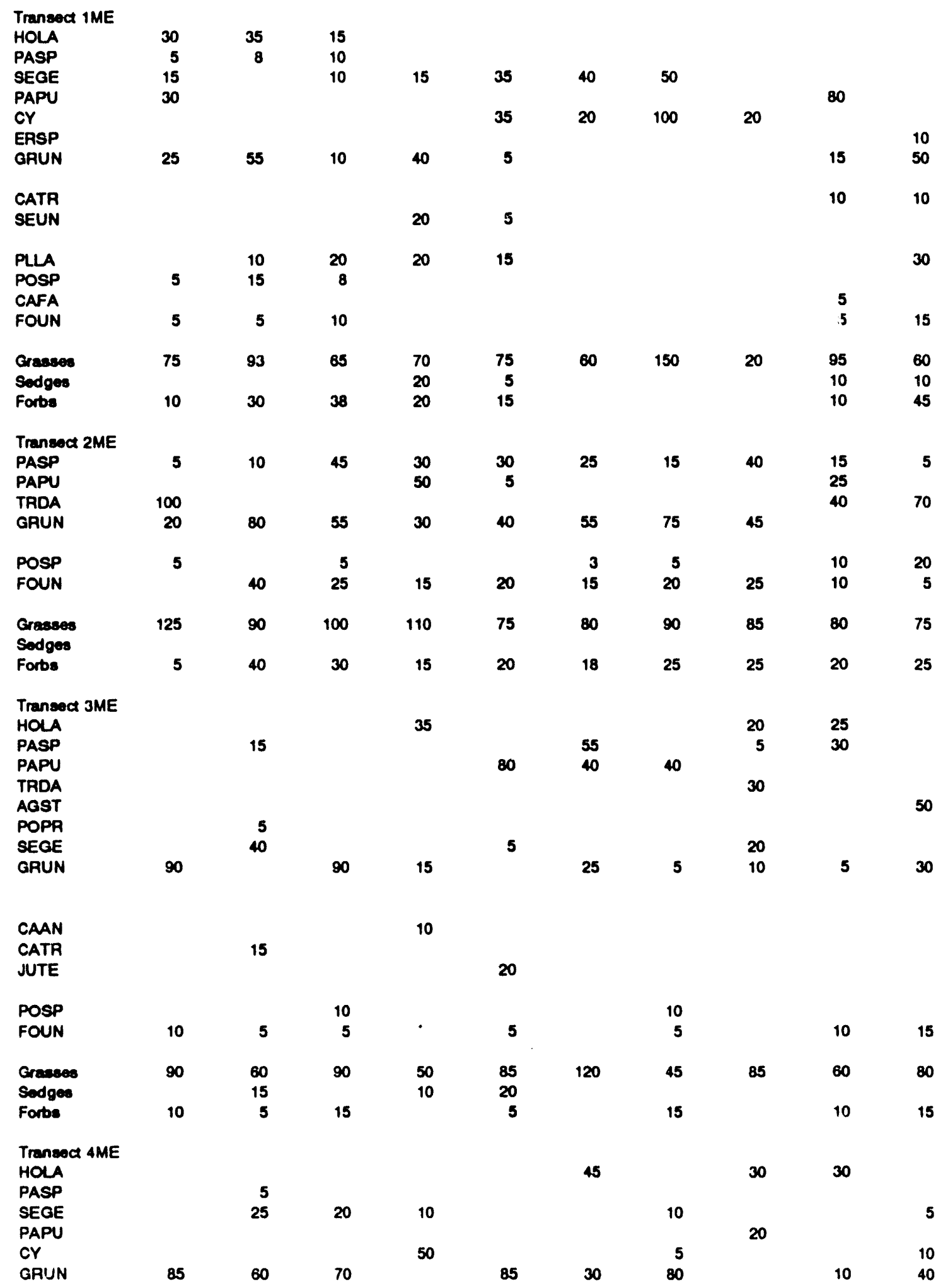


TABLE B.5. cont.

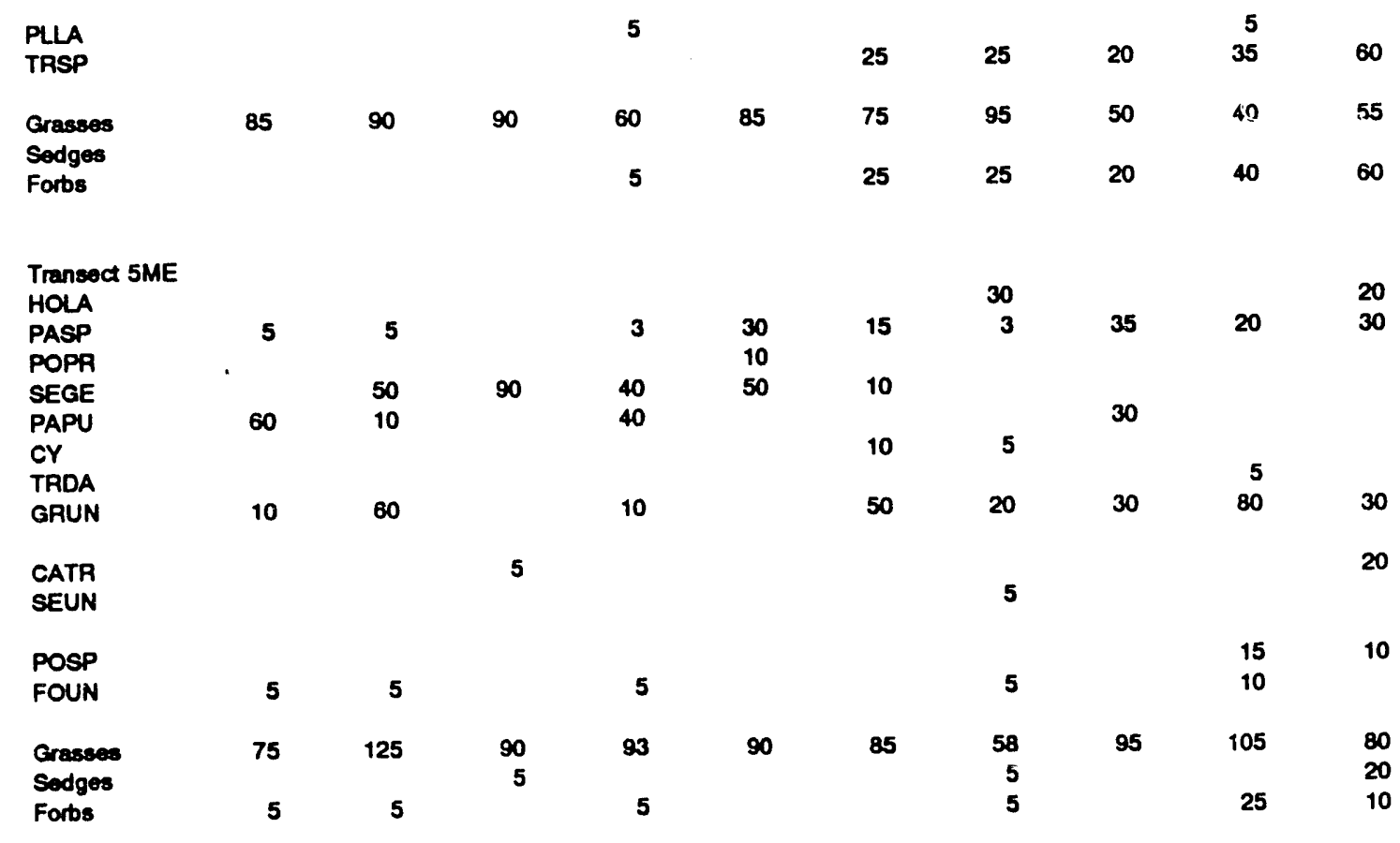

B.11 
TABLE B.6. Estimates of Vegetation Canopy Cover on Mowed, Unexposed Transects (1MU-5MU) in August

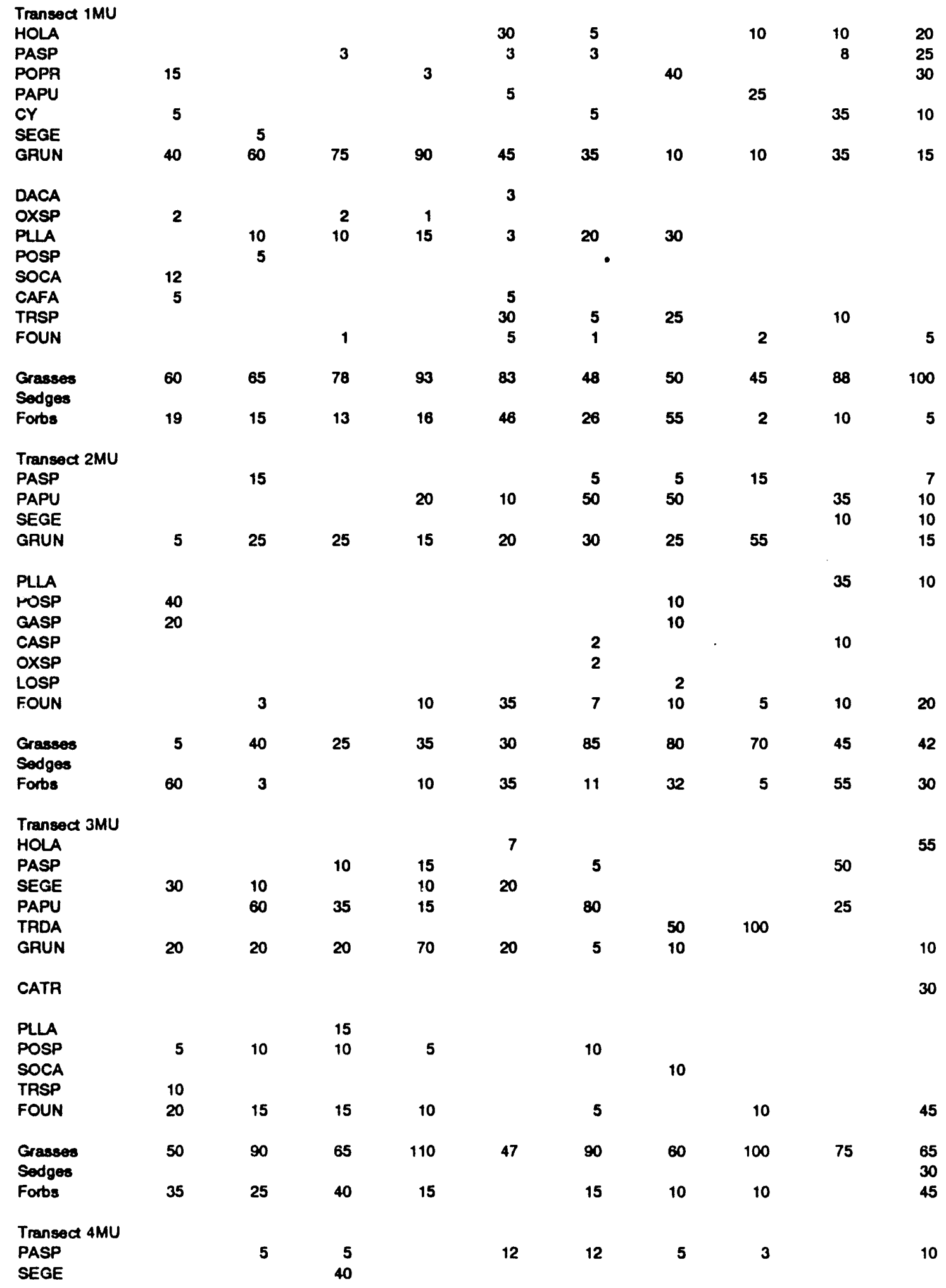


TABLE B.6. cont.

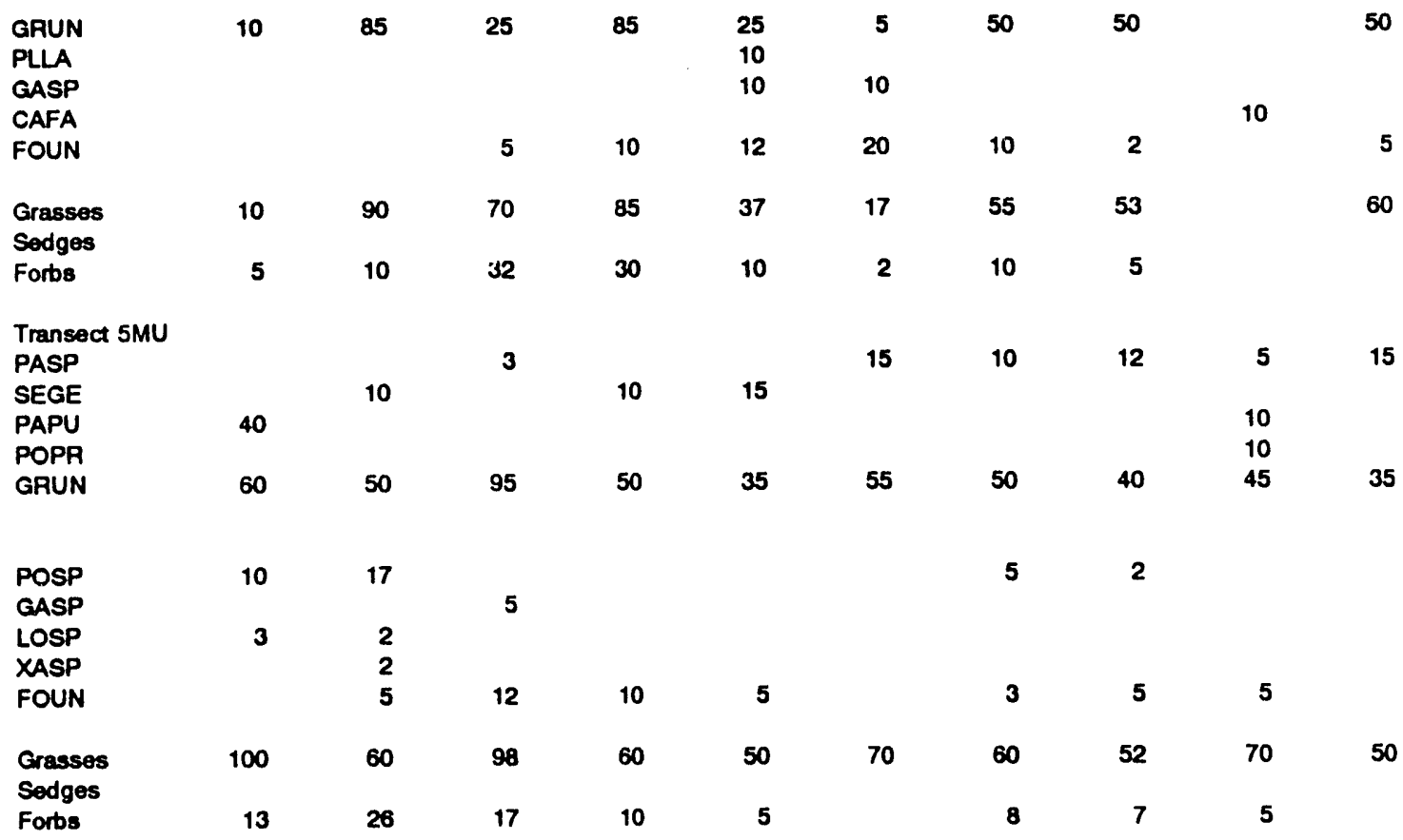


APPENDIX C

LIST OF RARE, THREATENED, AND ENDANGERED VERTEBRATES

THAT COULD OCCUR AT M-FIELD 


\section{APPENDIX C}

\section{LIST OF RARE, THREATENED, AND ENDANGERED VERTEBRATES THAT COULD OCCUR AT M-FIELD}

\begin{tabular}{l} 
Scientific Nane \\
\hline Ambystoma tigrinum \\
Aneides aeneus \\
Cryptobranchus alleganiensis \\
Gastrophryne carolinensis
\end{tabular}

\section{REPTILES}

Dermochelys coriacea Eretmochelys imbricata Eumeces anthracinus Farancia erytrogramma Lepidochelys kempii Virginia valeriae pulchra Falco peregrinus Haliaeetus leucocephalus Numenius borealis Picoides borealis

Erethizon dorsatum Lynx rufus Mustela nivalis Myotis sodalis Ursus americanus

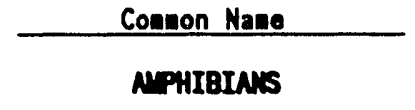

Eastern tiger salamander Green salamander Hellbender Eastern narrow-mouthed toad

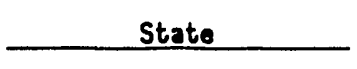

Endangered Endangered Endangered Endangered
Atlantic leatherback turtle Atlantic hawksbill turtle Northern coal skink Rainbow snake Atlantic ridley turtle Mountain earth snake Peregrine falcon Bald eagle Eskima curlew Red-cockaded woodpecker

\section{MAMMALS}

Porcupine

Bobcat

Least weasel

Indiana bat

Black bear

\author{
Endangered \\ Endangered \\ Endangered \\ Endangered Extirpated \\ Endangered \\ Endangered \\ Endangered \\ Endangered \\ Endangered Extirpated \\ Endangered Extirpated
}

In Need of Conservation In Need of Conservation In Need of Conservation Endangered

Rare 
APPENDIX D

TERRESTRIAL VERTEBRATES OF MARYLAND FOUND AT ABERDEEN THAT COULD OCCUR AT M-FIELD 


\section{TERRESTRIAL VERTEBRATES OF MARYLAND FOUND AT ABERDEEN THAT COULD OCCUR AT M-FIELD}

Scientific Name

Didelphis marsupalis virginians Sorex cinereus fontinalis Cryptotis parva parva Blarina brovicauda kirtandi Condylure cristata cristata Scalopus aquaticus aquaticus Various specios

Procyon loto

Mustola ermina cicognanii

Lutra canadensis lataxina Mephits mephit's nigra Vulpes vulpes fulve

Urocyon cineroargenteus cineroargenteus Marmota monax monax Tamias striatus fisheri Sciurus niger vulpinus Sciurus carolinensis pennsylvanicus Glaucomys volans volans Castor canadensis

Peromyscus loucopus noveboracensis Neotoma floridana magister Oryzomys palusiris palustris Microtus pennsytvanicus ponnsytvanicus Microtus pinetorum scalopsoides Ondatra zibethicus macrodon Zapus hudsonicus americanus Rattus norvegicus

Mus musculus

Sylvilagus floridanus mallurus Odocoileus virginianaborealis

\section{Common Name}

Occurrence

\section{MAMMALS}

Opossum
Masked shrew
Least shrew
Short-tailed shrew
Star-nosed mole
Eastern mole
Bats
Raccoon
Short-tailed weasel or
ermine
River otter
Striped skunk
Red fox
Grey fox
Woodchuck
Eastern chipmunk
Eastem fox squirrel
Eastern gray squirrel
Southem flying squirrel
Beaver
White-footed mouse
Eastern woodrat
Rice rat
Meadow vole
Pine vole
Muskrat
Meadow jumping mouse
Norway rat
House mouse
Eastem cottontail
White-tailed deer

BIRDS

Common loon

Homed grebe Pied-billed grebe Double-crested cormorant Great blue heron

\author{
Common \\ Uncommon \\ Least shrew Rare \\ Common \\ Rare \\ Rare \\ Uncommon \\ Common \\ Rare \\ Rare \\ Common \\ Common \\ Rare \\ Common \\ Common \\ Common \\ Common \\ Uncommon \\ Uncommon \\ Abundant \\ Rare \\ Uncommon \\ Abundant \\ Uncommon \\ Abundant \\ Common \\ Rare \\ Uncommon \\ Abundant \\ Abundant
}

Gavia immer

Podiceps auritus

Podilymbus podiceps

Phalacrocorax auritus

Ardea herodias
D.1 
Florida caerulea

Bubulcus ibis

Casmerodius albus

Leucophoyx thula

Butorides virescens

Ixobrychus exills

Botaurus lentiginosus

Fiegadus faicinelius

Fiegadus albus

Olor cobumbianus

Brania canadensis

Anas platyrtynchos

Anas rubripes

Anas stropera

Anas acute

Anas carolinensis

Anas discors

Mareca americana

Spatula clypeata

Aix sponse

Aythya americana

Aythya collaris

Aythya valisineria

Aythya marila

Bucophala clangula

Bucepha/a alboola

Oxyura jamaicensis

Lophodytes cucullatus

Morgus mergansor

Mergus serrator

Cathartes aura

Coragyps atratus

Accipiter striatus

Accipiter cooperii

Butoo lagopus

Butoo jamaicensis

Buteo lineatus

Butoo platypterus

Aquila chrysaotos

Hallaeotus leucocephalus

Cincus cyanous

Pandion haliaetus

Falco columbarius

Falco sparvorius

Moleagris gallopavo

Colinus virginiahus

Phasianus colchicus

Rallus elegans

Rallus limicola

Gallinule chloropus

Porzana camolina

Laterallus jamcicensis

Fulica americana

Charadrius wilisonia

Charadrius vociforus

Squatarola squatarola
Little blue heron

Cattle egret

Common egret

Snowy egret

Green heron

Least bittern

Americian bittern

Glosey ibss

White ibss

Whistling swan

Canada goose

Mallard

Black duck

Gadwall

Pintail

Green-winged teal

Blue-winged toal

American widgen

Shoveler

Wood duck

Redhead

Ring-necked duck

Canvasback

Greater scaup

Common goldeneye

Bufflehead

Ruddy duck

Hooded merganser

Common merganser

Red-breasted merganser

Turkey vulture

Black vulture

Sharp-chinned hawk

Cooper's hawk

Rough-legged hawk

Red-tailed hawk

Red-shouldered hawk

Broad-winged hawk

Golden eagle

Bald eagle

Marsh hawk

Osprey

Pigeon hawk

Sparrow hawk

Turkey

Bobwhite

Aing-necked pheasant

King rail

Virginia rail

Common gallinule

Sora

Black rail

American coot

Wilson's plover

Killdeer

Black-bellied plover 
Philohela minor

Capella gallinago

Actitis macularia

Tringa solitaria

Catoptrophorus semipolmanus

Totanus melanoleucus

Totanus flavipes

Erolia melanotos

Enolia minutilla

Erolia alpina

Limnodromus griseus

Ereunetes pusillus

Larus marinus

Lanus argenatus

Lanus delawarensis

Lanus atricilla

Larus philadelphia

Sterna albifrons

Hydroprogne caspia

Columba livia

Zenaidura macroura

Coccyzus americanus

Bubo virginianus

Asio flammeus

Tyto alba

Strix varia

Caprimulgus carolinnesis

Caprimulgus vociforus

Chaetura pelagica

Archilochus colubris

Megaceryle alcyon

Colaptes auratus

Sphyrapicus varius

Centurus carolinus

Dendrocopos villosus

Dendrocopos pubescens

Tyrannus tyrannus

Myiarchus crinitus

Sayornis phoobo

Empidonax virescens

Contopus virens

Nuttallomis borealis

Eremophila alpestris

Iridoprocne bicolar

Riparia riparia

Stolgidoptenx ruficollis

Hirundo rustica

Progne subis

Cyanocitta cristata

Corvus brachyrtynchos

Convis ossifragus

Parus carolinensis

Parus bicolar

Sitta carolinensis

Certhia tamilaris
American woodcock

Common snipe

Spotted sandpiper

Solitary sandpiper

Willet

Greatest yellowlegs

Lesser yellowlegs

Pectoral sandpiper

Least sandpiper

Dunlin

Short-billed dowitcher

Semipalmated sandpiper

Great black-backed gull

Herring gull

Aing-billed bull

Langhing gull

Bonaparte's gull

Least tem

Caspian tern

Rock dove

Mouming dove

Yellow-billed cuckoo

Great homed owl

Shorteared owl

Bam owl

Barred ow

Chuck-will's-widow

Whip-poor-will

Chimney swift

Ruby-throated hummingbird

Belted kingfisher

Yellow-shafted flicker

Yellow-bellied sapsucker

Red-bellied woodpecker

Hairy woodpecker

Downy woodpecker

Eastern kingbird

Great crested flycatcher

Eastom phoebe

Acadian flycather

Eastern wood pewee

Olive-sided flycatcher

Horned lark

Tree swallow

Bank swallow

Rough-winged swallow

Barn swallow

Purple martin

Blue jay

Common crow

Fish crow

Carolina chuckadee

Titmouse

White-breasted nuthatch

Brown creeper 
Troglodytes troglodytes

Thryothorus ludovicianus Tolmaaatodytos palustris Mimus polyglottos

Dumetella carolinensis

Toxostoma rufum

Turdus migratorius

Hylocichla mustolina

Hylocichla guttato

Hylocichla ustulata

Hylocichla fuscescens

Sialia sialis

Polioptila caerulea

Regulus satrapa

Regulus calendula

Bombycillia cedrorum

Stunus vulgaris

Vireo griseus

Vireo olivaceus

Mniotilta varia

Vormivora pinus

Vermivora peregrina

Parula americana

Dendroica petochie

Dendroica magnolia

Dendroica tigrine

Dendroica caoruloscens

Dendroica coronata

Dendroica virens

Dendroica fusca

Dendroica pensylvanica

Dendroica castanea

Dendroica straita

Dendroica pinus

Dondroica discolor

Dondroica palmanum

Seiurus aurocapillus

Seiunis novoboracensis

Seiurus motacilla

Geothlypis trichas

Icteria virens

Wilsonia pusilla

Wilsonia canadensi

Setophaga ruticilla

Passer domesticus

Dolichonyx onzivorus

Stumella magna

Agelaius phoeniceus

Icterus spurius

lceterus galbula

Euphagus carolinus

Quiscalus quiscula

Molothrus ater

Piranga olivacea

Piranga rubra

Richmondena cardinalis
Winter wren

Carolina wren

Long-billed marsh wren

Mockingbird

Catbird

Brown thrasher

Robin

Wood trush

Hermit thrush

Swainson's thrush

Veery

Eastem bluebird

Bluo-gray gnatcatcher

Golden-crowned kinglet

Ruby-crowned kinglet

Cedar waxwing

Starling

Whito-eyed vireo

Red-eyed vireo

Black-and-white warbler

Blue-winged warbler

Tennessee warbler

Parula warbler

Yellow warbler

Magnolia warbler

Cap May warbler

Black-throated blue warbler

Myrtie warbler

Black-throated green warbler

Blackburnian warbler

Chestnut-sided warbler

Bay-breasted warbler

Blackpoll warbler

Pine warbler

Prairie warbler

Palm warbler

Ovenbird

Northem waterthrush

Louisiana waterthrush

Yellowthroat

Yellow-breasted chat

Wilson's warbler

Canada warbler

American redstart

House sparrow

Bobolink

Eastem meadowlark

Red-winged blackbird

Orchard oriole

Baltimore oriole

Rusty blackbird

Common grackle

Brown-headed cowbird

Scarlet tanager

Summer tanager

Cardinal

\section{D.4}


Phoucticus ludovicianus

Guiraca caerulea

Passerina cyanea

Spinus tristis

Pipilo enthrophthalmus

Passerculus sancwichensis

Ammodramus savannarum

Pooecetes gramineus

Junco hyomalis

Spizella arborea

Spizella passerina

Spizella pusilla

Zonotrichia loucophrys

Zonotrichia albicollis

Passerella illaca

Metospiza georgiana

Melospiza melodia

Plectrophenax nivalis

Rose-breasted grosbeak

Blue groabeak

Indigo bunting

American goldfinch

Rufous-sided towhee

Savannah sparrow

Grasshopper sparrow

Vesper spartow

State-colored junco

Tree sparrow

Chipping sparrow

Field sparrow

White-crowned sparrow

White-throated sparrow

Fox sparrow

Swamp sparrow

Song sparrow

Snow bunting

\section{AMPHIBIANS AND REPTILES}

Ambystoma maculatum Ambystoma opacum

Plethodon c. cinerous

Bufo a. americanus

Buto woodhousei fowleri

Acris crepitans crepitans

Hyla cineroa

Hyla c. crucifor

Hyla v. versicolor

Pseudacris triseriata foriarum
Spotted salamander Marbled salamandor Red-backed salamander American toad

Fowler's toad

Northem cricket frog

Green treefrog

Northem spring peeper

Eastem gray treetrog

Upland chorss frog
Common Uncommon

Common

Common

Abundant

Abundant

Uncommon

Abundant

Abi:nriant

Common 


\section{DISTRIBUTION}

No. of

Copies

OFFSITE

2 DOE/Office of Scientific and Technical Information

5 Dr. Randall Wentsel

U.S. Army Chemical Research, Development and Engineering Center

SMCCR-RST-E

Bldg. E3220

Edgewood Area

Aberdeen Proving Ground, MD 21010.5423

5 Dr. Carl Phillips

U.S. Army Chemical Research, Development and Engineering Center

SMCCR-RST-E

Bldg. E3220

Edgewood Area

Aberdeen Proving Ground, MD 21010-5423
No. of

Copies,

\section{ONSITE}

DOE Richland Field Office

P. W. Kruger

21 Pacific Northwest Laboratory

D. A. Cataldo

J. L. Downs (5)

L. E. Eberhardt (2)

J. W. Falco

R. E. Fitzner (2)

J. M. Thomas

L. E. Rogers (2)

P. C. Hays

Publishing Coordination

Technical Report Files (5) 


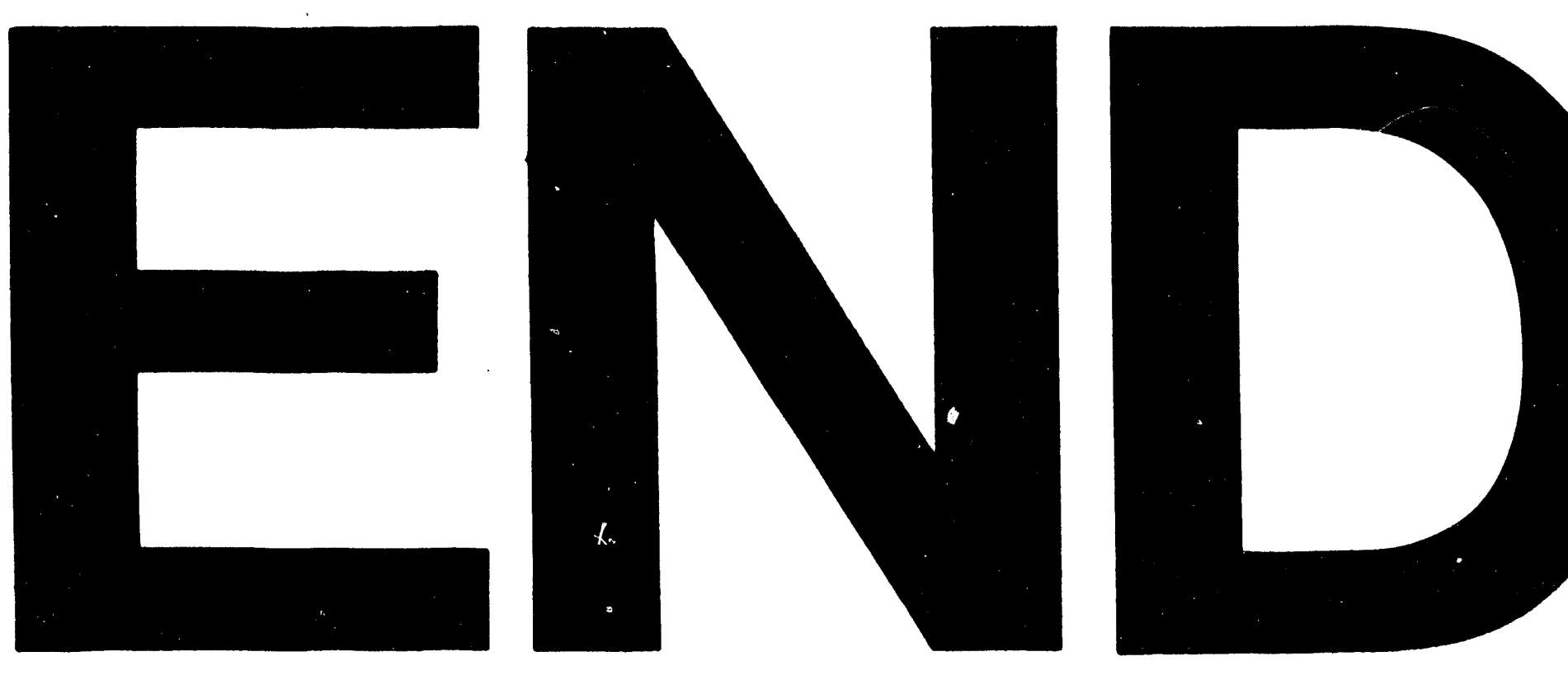

I
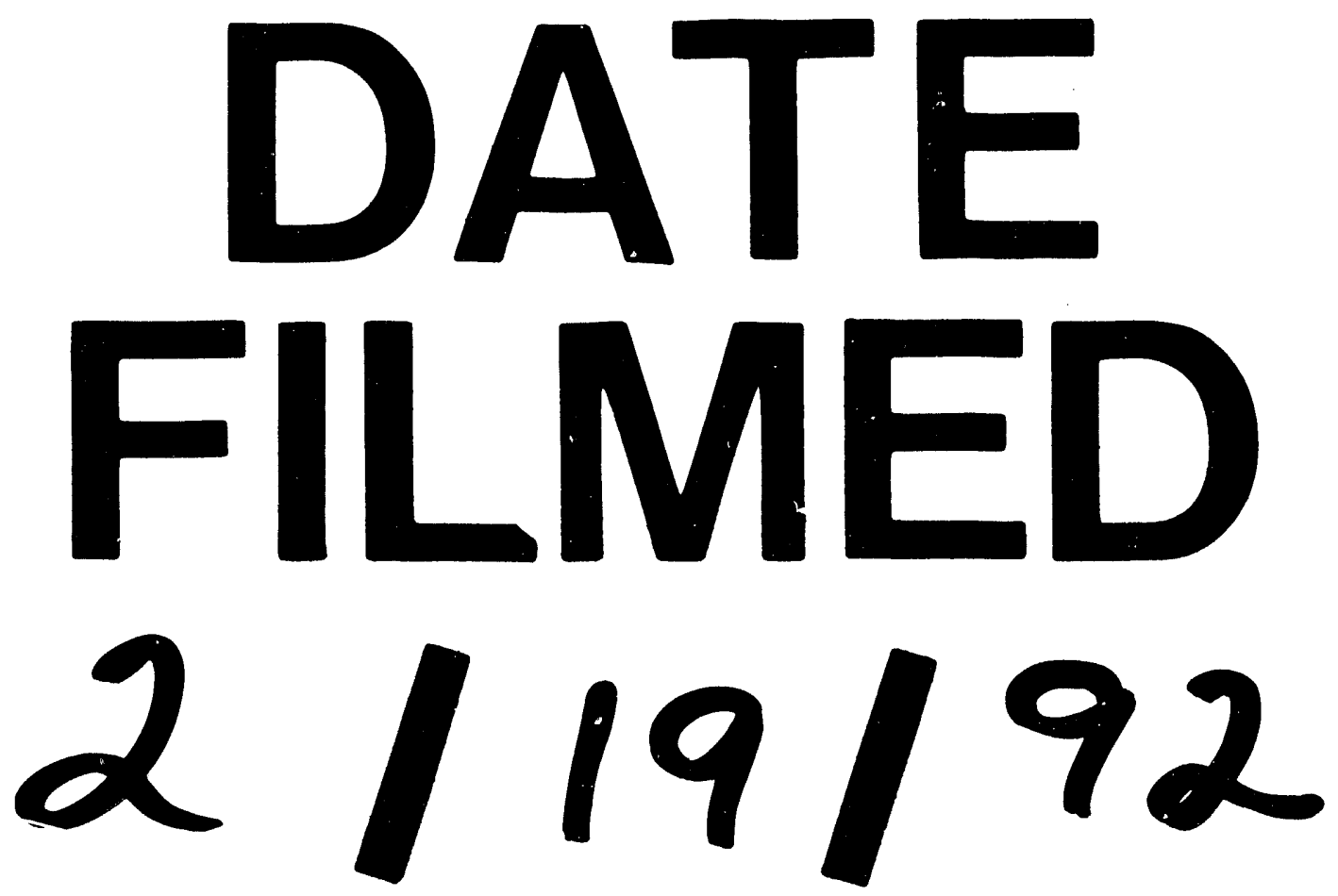


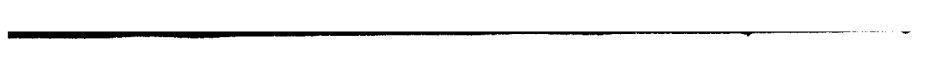

